8 E-mail address: liwei.zhang@ @etl.doe.gov

\title{
Numerical simulation of porosity and permeability evolution of Mount Simon sandstone under geological carbon sequestration conditions
}

\author{
$7 *$ Corresponding author. \\ Liwei Zhang*, Yee Soong, Robert Dilmore, and Christina Lopano \\ U.S. Department of Energy, National Energy Technology Laboratory, 626 Cochrans Mill Road, P.O. Box \\ 10940, Pittsburgh, PA 15236
}

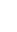

\section{Abstract}

A numerical model was developed with the use of reactive transport code CrunchFlow to estimate porosity, permeability and mineral composition changes of Mount Simon sandstone under typical geological carbon sequestration conditions $\left(P=23.8 \mathrm{MPa}\right.$ and $\left.T=85^{\circ} \mathrm{C}\right)$. The model predicted a permeability decrease from $1.60 \mathrm{mD}$ to $1.02 \mathrm{mD}$ for the Mount Simon sandstone sample in a static batch reactor after 180 days of exposure to $\mathrm{CO}_{2}$-saturated brine, which is consistent with measured permeability results. Model-predicted solution chemistry results were also consistent with laboratory-measured solution chemistry data. $\mathrm{SiO}_{2}$ (am) was the primary mineral that causes permeability decrease, followed by kaolinite. Both $\mathrm{SiO}_{2}$ (am) formation and kaolinite formation were attributed to the dissolution of quartz and feldspar. This study shows that the formation of $\mathrm{SiO}_{2}(\mathrm{am})$ and kaolinite in the pore space of host rock is possible under typical $\mathrm{CO}_{2}$ sequestration conditions. $\mathrm{SiO}_{2}(\mathrm{am})$ and kaolinite precipitation at the $\mathrm{CO}_{2}$ plume extent could reduce the permeability of host rock and improve lateral containment of free-phase $\mathrm{CO}_{2}$, contributing to overall security of $\mathrm{CO}_{2}$ storage. 
25 Key words: $\mathrm{CO}_{2}$ sequestration; sandstone formation; reactive transport model; permeability; 26 porosity

\section{Introduction}

29 Carbon capture and sequestration (CCS), which involves capture of large quantities of carbon 30 dioxide from flue gas and injecting carbon dioxide into permeable geological formations at depth

31 (Gasda et al., 2008) sufficient to ensure safe long-term storage, is a promising strategy to reduce

32 the emissions of greenhouse gas to the atmosphere. Projections by the Global CCS Institute 33 (2011) suggest that CCS would need to account for $19 \%$ of total $\mathrm{CO}_{2}$ emission reduction to 34 reach the $\mathrm{CO}_{2}$ emission target by 2050. Deep saline aquifers have been reported to have the 35 highest estimated $\mathrm{CO}_{2}$ storage capacity of all candidate geologic storage targets - at least 1738 36 Gigatonnes of $\mathrm{CO}_{2}$ in North America alone (The North American Carbon Storage Atlas, 2012).

37 The interaction between injected $\mathrm{CO}_{2}$ and host rock in deep saline aquifers for $\mathrm{CO}_{2}$ sequestration

38 is of interest because a) the interaction between injected $\mathrm{CO}_{2}$ and host rock may result in porosity 39 and permeability changes of host rock, which would directly impact $\mathrm{CO}_{2}$ storage capacity, $\mathrm{CO}_{2}$ 40 plume migration, and reservoir pressure response; b) the interaction between injected $\mathrm{CO}_{2}$ and 41 host rock may result in permanent storage of some of injected $\mathrm{CO}_{2}$ as carbonate minerals, and 42 could potentially release unwanted ions (e.g., arsenic from arsenopyrite in host rock,

43 Parthasarathy et al., 2011) to the aquifers.

45 There is a wide range of pressure and temperature for $\mathrm{CO}_{2}$ sequestration conditions. The pressure 46 can range from $7.3 \mathrm{MPa}$ to $65 \mathrm{MPa}$ and the temperature can range from $31^{\circ} \mathrm{C}$ to $132{ }^{\circ} \mathrm{C}$. In this

47 study, the $\mathrm{CO}_{2}$ sequestration conditions are defined as a pressure of $23.8 \mathrm{MPa}$ and a temperature 
48 of $85{ }^{\circ} \mathrm{C}$, which correspond to a formation depth of around $2.4 \mathrm{~km}$ given a pressure gradient of $49 \quad 10^{4} \mathrm{~Pa} / \mathrm{m}$.

51 There have been a number of experimental studies that investigated the physical and chemical

52 property changes of host $\mathrm{CO}_{2}$ storage rock when exposed to $\mathrm{CO}_{2}$ (Luquot and Gouze, 2009; $\mathrm{Fu}$

53 et al., 2009; Morris et al., 2009; Lu et al., 2011; Liu et al., 2012; Luquot et al., 2012; Carroll et al.,

54 2012; Karamalidis et al., 2012; Soong et al., 2014). Important conclusions that can be derived

55 from those previous studies are: a) the nature of physical and chemical changes of host rock is

56 dependent on its mineral composition, and on the progressive dissolution of $\mathrm{CO}_{2}$ that results in a

57 decrease of $\mathrm{pH}$ in brine (Luquot and Gouze, 2009). b) $\mathrm{CO}_{2}$-sandstone interaction usually does

58 not result in formation of $\mathrm{CaCO}_{3}$ within short exposure period (Carroll et al., 2012; Soong et al.,

59 2014), but slow dissolution of feldspar minerals would cause $\mathrm{CaCO}_{3}$ to ultimately precipitate

60 (Kharaka et al., 2013). More carbonate minerals would ultimately precipitate from sandstones

61 that have abundant feldspar minerals and where the feldspars are more calcic (Kharaka et al.,

62 2013). c) dissolution of feldspar in feldspar-rich host rock usually results in precipitation of

63 secondary clay minerals (e.g., montmorillinite and kaolinite) (Fu et al., 2009; Liu et al., 2012;

64 Carroll et al., 2012); and precipitation of secondary clay minerals can offset porosity and

65 permeability changes as a result of feldspar dissolution (Soong et al., 2014).

66

67 Results from experimental studies help researchers identify key geochemical reactions and

68 enable insights into reaction pathways of host rock- $\mathrm{CO}_{2}$ interaction under $\mathrm{CO}_{2}$ sequestration

69 conditions. Results from experimental studies also help develop and constrain geochemical

70 models. However, experimental studies have limitations. First, they are limited to relatively short 
71 time scales (typically days to months), and it is difficult to predict long-term physical and

72 chemical property changes of host rock (e.g., 30-1000 years) under $\mathrm{CO}_{2}$ sequestration conditions.

73 Second, rigorous experimental exploration of parameter space for controlling variables, such as

74 initial porosity of host rock, feldspar wt\% of host rock and aqueous $\mathrm{CO}_{2}$ concentration after $\mathrm{CO}_{2}$

75 injection, are time-consuming, expensive and sometimes not feasible in the laboratory.

76 Computer-based reactive transport modeling overcomes these limitations, enabling extrapolation

77 of findings from relatively short experiments to longer time scales and parameter sensitivity

78 analyses (Gunter et al., 1997; Gaus et al., 2005; Johnson et al., 2005; Xu et al., 2011; Gherardi et

79 al., 2012). There have been some studies that focused on modeling of interactions between $\mathrm{CO}_{2}$ -

80 saturated brine and reservoir host rock (or caprock). Johnson et al. (2005) used a reactive

81 transport model to assess the evolution of caprock permeability due to $\mathrm{CO}_{2}$ injection-induced

82 mineral alteration. Zerai et al. (2006) conducted equilibrium, path-of-reaction and kinetic

83 modeling of $\mathrm{CO}_{2}$-brine-mineral reactions in the Rose Run Sandstone in Ohio to investigate the

84 factors that are likely to influence the capacity of this formation to trap injected $\mathrm{CO}_{2}$. Xu et al.

85 (2011) applied a generic two-dimensional (2-D) radial TOUGHREACT model to illustrate the

86 temporal evolution and spatial distribution of the injected $\mathrm{CO}_{2}$ and the subsequent physical and

87 chemical changes of the reservoir host rock under $\mathrm{CO}_{2}$ sequestration conditions. Liu et al. (2011)

88 performed numerical simulation of large scale $\mathrm{CO}_{2}$ injection (a million tons per year for 100

89 years) into Mount Simon sandstone. Gherardi et al. (2012) also applied TOUGHREACT code to

90 predict mineral alteration in both the cement of an idealized abandoned wellbore and the caprock

91 adjacent to the wellbore at the top of a potential $\mathrm{CO}_{2}$ storage aquifer (Dogger aquifer) in Paris

92 Basin, France. 
94 Most reactive transport models to study the interaction between host rock and $\mathrm{CO}_{2}$-saturated

95 brine rely on kinetic and equilibrium constants that are uncertain (or maybe even unreliable). So

96 it is prudent to compare modeling results with experimental results to help understand the

97 implications of model predictions, and to explore sensitivity of model results to reasonable

98 perturbation of those key parameters. One study investigated the mineral composition change of

99 Mount Simon sandstone samples after exposure to $\mathrm{CO}_{2}$-saturated brine with the use of reactive

100 transport modeling, and the mineral composition results from modeling were compared with

101 experimental data (Carroll et al., 2012). However, more studies are needed to compare modeling

102 results with experimental data.

104 In this study, a numerical model that is able to simulate porosity, permeability and mineral 105 composition changes of host rock under $\mathrm{CO}_{2}$ storage conditions is presented. The model is 106 compared with experimental results (permeability and solution chemistry data) from Soong et al.

107 (2014). Both the model and the experimental study done by Soong et al. (2014) are

108 representative of the post $\mathrm{CO}_{2}$ injection period where the $\mathrm{CO}_{2}$ plume is stabilized and the system 109 pressure returns to pre-injection values. In the experiment of Soong et al., one cylindrical

110 sandstone sample $(2.54 \mathrm{~cm}$ in diameter $\times 5.08 \mathrm{~cm}$ in length $)$ obtained from a depth of $1,769.7 \mathrm{~m}$

111 from a well located in Vermillion County, IN was exposed to $\mathrm{CO}_{2}$-saturated brine $\left(P\left(\mathrm{CO}_{2}\right)=\right.$

$11223.8 \mathrm{MPa}$ and temperature $=85^{\circ} \mathrm{C}$ ) in a static (no flow) high pressure vessel with a Teflon liner.

113 The exposure time was 180 days. The initial brine composition in the experiment of Soong et al.

114 (2014) is shown in Table 1. An equilibrium calculation based on initial brine composition and

115 exposure conditions was performed using CrunchFlow to take into account potential mineral 116 super-saturation at elevated temperature under given exposure conditions. The brine composition 
117 after equilibrium calculation is reported in Table 1. Despite significant concentration decrease

118 for $\mathrm{Ba}^{2+}, \mathrm{H}_{4} \mathrm{SiO}_{4}(\mathrm{aq})$ and $\mathrm{Al}^{3+}$ shown in Table 1 , CrunchFlow does not predict any mineral

119 precipitation when the system reaches equilibrium, which implies that minerals that have

120 potential to precipitate (i.e., $\mathrm{BaSO}_{4}$ and $\mathrm{K}_{0.85} \mathrm{Al}_{2.85} \mathrm{Si}_{3.15} \mathrm{O}_{10}(\mathrm{OH})_{2}$ ) have not reached super-

121 saturated state. Therefore, the sandstone porosity change after 180 days of exposure is caused by

122 interaction between sandstone and brine, not precipitation of minerals from super-saturated brine.

123 More details about the experiment can be found in Soong et al. (2014).

125 Most previous studies are focused on the reaction pathways for interaction between host rock and $126 \mathrm{CO}_{2}$-saturated brine, while the correlation between chemical reactions and change in porosity 127 and permeability has not been extensively studied. This study demonstrates a methodology to 128 couple reactive transport modeling and permeability evolution modeling, and the results from 129 this study provide a link between chemical reaction and permeability change. A comprehensive 130 sensitivity analysis is conducted to investigate how the changes of important modeling 131 parameters affect permeability evolution, which has not been reported in previous studies.

132 Though the simulations performed in this study are not field scale, the results from this study can 133 be used to demonstrate how chemical reactions might affect the permeability of Mount Simon 134 formation after injection of $\mathrm{CO}_{2}$.

135 2. Model description

$136 \quad 2.1$ Model set up

137 A 1-D reactive transport model was developed with the use of the multicomponent reactive 138 transport modeling code CrunchFlow (Steefel, 2009). The model simulates interactions between 
$139 \mathrm{CO}_{2}$-saturated brine and a Mount Simon sandstone sample, and yields mineral composition and 140 porosity changes of the sample. The model is focused on the post injection period, and the 141 simulations performed were able to capture the conditions at locations close to the $\mathrm{CO}_{2}$ plume 142 after injection of $\mathrm{CO}_{2}$ (i.e., near-static (no flow) condition, pressure is close to pre-injection 143 reservoir pressure, and brine is saturated with $\mathrm{CO}_{2}$ ). Two scenarios with different simulation

144 durations were tested. The first scenario had a modeled reaction time of 180 days, which was the 145 same as the exposure time of the sandstone exposure experiment (Soong et al., 2014); the second 146 scenario had a modeled reaction time of 30 years, which was selected to explore permeability 147 and porosity changes of the sandstone sample after very long exposure time.

149 A schematic of the modeling region is illustrated in Figure 1. In the 1-D model, the sandstone 150 sample is divided into 1,000 grid blocks and each block has a length of $2.54 \times 10^{-3} \mathrm{~cm}$. The ratio 151 of the brine domain width $(296 \mathrm{~mm})$ to sandstone domain width $(25.4 \mathrm{~mm})$ equals to the ratio of 152 brine volume to sandstone volume in the high pressure vessel, so as to accurately model solution 153 chemistry. The model is a closed boundary model with no flow, which mimics the conditions in 154 the high pressure vessel. The model requires inputs of equilibrium constants and rate constants 155 for dissolution and precipitation reactions of minerals, which yields volume fraction changes of 156 minerals at each grid block. Key model input parameters are discussed in Section 2.4. Change of 157 porosity at each grid block is correlated with volume fraction changes of minerals by equation 158 (1):

$$
\phi(t)=1-\sum_{i=1}^{m} f r_{i}(t)-f r_{n}
$$

where, 
$161 \phi(t)$ is the porosity at time $t, f r_{i}(t)$ is the volume fraction of reactive mineral phase $i$ at time $t$ and $162 f r_{n}$ is the volume fraction of all inert mineral phases. In this study, all mineral phases involved 163 are active and there are no inert phases. The initial porosity of the sample $(\varnothing(t=0))$ is equal to $1647.9 \%$, and the porosity was measured using a helium porosimeter (HP-41, Temco, Inc) at 0.7 $165 \mathrm{MPa}$ and ambient temperature (Soong et al., 2014).

167 The volume fraction of each mineral can be calculated with the use of mineral molar fraction and 168 the molar volume of each mineral:

$$
f r_{i}(t)=\frac{\operatorname{Mol}_{i}(t) \times V_{\text {molar }-i}}{\sum_{i=1}^{n} \operatorname{Mol}_{i}(t) \times V_{\text {molar }-i}}
$$

169 where,

$170 \operatorname{Mol}_{i}(t)$ is molar fraction of mineral $i$ at time $t$ and $V_{\text {molar }-i}$ is molar volume of mineral $i$. Molar 171 volumes of all minerals are listed in Table 2.

173 CrunchFlow uses the law of transition state theory (TST) to calculate mineral precipitation and

174 dissolution rates. The simplified expression of the mineral dissolution/precipitation rate law can 175 be written as (Steefel, 2009):

176

$$
\mathrm{R}_{\mathrm{ir}}=\mathrm{A}\left(\sum_{\mathrm{l}=1}^{\mathrm{M}} \mathrm{k}_{\mathrm{l}}\left(\prod_{\mathrm{i}=1}^{\mathrm{N}} \mathrm{a}_{\mathrm{i}}^{\mathrm{p}_{\mathrm{i}}}\right)\left(1-\frac{\mathrm{Q}}{\mathrm{K}_{\mathrm{eq}}}\right)\right.
$$

177 where, 
$178 \mathrm{~A}$ is the specific surface area of the mineral involved in the reaction, $k_{l}$ is the $l^{\text {th }}$ parallel reaction

179 rate constant that contributes to the dissolution/precipitation of the mineral, $\prod_{i=1}^{N} a_{i}^{p_{i}}$ describes

180 the effects of various ions in solution on the dissolution/precipitation rate of parallel reaction $l, \mathrm{Q}$

181 is ion activity product (e.g., for reaction $\mathrm{aA}+\mathrm{bB} \leftrightarrow \mathrm{cC}+\mathrm{dD}$, Q is equal to $\frac{[\mathrm{C}]^{\mathrm{c}}[\mathrm{D}]^{\mathrm{d}}}{[\mathrm{A}]^{\mathrm{a}}[\mathrm{B}]^{\mathrm{b}}}$ ), and $\mathrm{K}_{\mathrm{eq}}$ is

182 equilibrium constant of the reaction. The ratio of $\mathrm{Q}$ to $\mathrm{K}_{\mathrm{eq}}\left(\mathrm{Q} / \mathrm{K}_{\mathrm{eq}}\right)$ determines the direction of the

183 reaction. For example, given calcite dissolution reaction $\mathrm{CaCO}_{3}+\mathrm{H}^{+} \leftrightarrow \mathrm{Ca}^{2+}+\mathrm{HCO}_{3}{ }^{-}$, if $\mathrm{Q}$ is

184 higher than $\mathrm{K}_{\mathrm{eq}}$, then the system is supersaturated with $\mathrm{Ca}^{2+}$ and $\mathrm{HCO}_{3}{ }^{-}$, and the reaction will

185 proceed in the direction of calcite precipitation. Rate constants and $\prod_{i=1}^{N} a_{i}^{p_{i}}$ values used in this

186 study are described in Section 2.4.

\section{$187 \quad 2.2$ Solution chemistry modeling}

188 The dissolution and precipitation of minerals result in concentration changes of cations and 189 anions within the pore space of the sandstone, and the cations and anions released to the pore 190 space will migrate to bulk brine driven by diffusive transport. In this study, the concentrations of 191 major elements in bulk brine (i.e., $\mathrm{Ca}, \mathrm{Na}, \mathrm{Mg}, \mathrm{K}, \mathrm{Fe}$ and $\mathrm{Si}$ ) after 180 days of exposure were 192 modeled and the modeled concentrations were compared with concentrations measured by 193 Soong et al. (2014) to make sure that the model captures key mineral dissolution and 194 precipitation processes. In Soong et al. (2014), brine solution from the high-pressure vessel was 195 filtered, acidified and diluted, and then analyzed with the use of a Dionex DX-100 ion 196 chromatograph equipped with a conductivity detector (Dionex, Inc. - Sunnyvale, CA, USA) 197 (Soong et al., 2014) to determine major element concentrations. The concentrations were only 198 measured at the end of the exposure experiment (i.e., $t=180$ days). 


$$
\operatorname{perm}_{v, t}=\frac{\sum_{i=1}^{n} h_{i} \operatorname{perm}_{i, t}}{L}
$$

217 where perm $_{v, t}$ is the vertical permeability at time $t ; L$ is the width of the sample $(2.54 \mathrm{~cm}) ; h_{i}$ is 218 the width of the individual block $\left(2.54 \times 10^{-3} \mathrm{~cm}\right) ;$ perm $_{i, t}$ is the local permeability in the block $i$

219 at time $t$, and $n$ is the total number of blocks $(1,000)$.

where perm $_{i, t}$ is the local permeability in the block $i$ at time $t$; perm $i, 0$ is the initial permeability in the block $i\left(1.6 \mathrm{mD}\right.$ for every block); $\Phi_{i, t}$ is the porosity in the block $i$ at time $t ; \Phi_{i, 0}$ is the initial porosity in the block $i$. Hereby the initial porosity at each grid block is assumed to be equal to the initial porosity of the entire sample $(7.9 \%)$, because the helium porosimeter method used by Soong et al. for porosity measurement can only yield the porosity of the entire sample, and the method does not provide characterization of porosity distribution of the sample. Therefore, the initial porosity at each grid block cannot be specified. $n$ is an exponential coefficient, which is set to be 11. The large $n$ value is suggested by Brunet et al. (2013) and is consistent with observations and quantification for porosity-permeability evolution induced by chemical reactions (Brunet et al., 2013).

The correlation between the overall permeability and the permeability of each block can be written as (Craft et al., 1991): 
221 Compared with complicated permeability calculation models such as Bautista-Manero-Puig

222 (BMP) model (Turcio et al., 2013) and lattice Boltzmann (LB) model (White et al., 2006), this

223 simple permeability model is easy to use and is sufficient for permeability calculation given

224 known initial permeability and porosity.

225

226 The modeled vertical permeability after 180 days of exposure $\left(\right.$ perm $\left._{v, 180}\right)$ was compared with

227 laboratory-measured vertical permeability of the sample. An Autolab 1500 unit from New

228 England Research, Inc. was implemented for permeability measurements. The central part of the

229 Autolab 1500 apparatus is a high pressure chamber, where confining pressure is created to

230 simulate underground conditions. A porous core sample is secured in a core holder and placed

231 inside the pressure chamber. A pressure transient method was used for permeability

232 measurements. During every individual measurement, the confining pressure was maintained at a

233 constant value (42 $\mathrm{MPa}$ ) to simulate actual field conditions. A pressure pulse was introduced at

234 the upstream side, and the pressure at the downstream side was recorded. Based on the observed

235 downstream pressure pulse, the permeability of the core sample was determined. During the

236 measurement, the sample was held for several hours under continuous nitrogen "flow through" at

237 the rates of about $0.1-0.2 \mathrm{~mL} / \mathrm{sec}$. More details of permeability measurement can be found in

238 Soong et al. (2014). It is important to note that no subcores were taken across the core to capture

239 the permeability of different zones.

241 In the batch reactor, the reactions are governed by diffusion, not permeability. However,

242 reactions driven by diffusion cause dissolution and precipitation of minerals, which result in 
243 permeability change of the sample. Therefore, permeability change is a result of diffusion-driven 244 reactions and the permeability change does not affect reactions in the batch reactor.

\subsection{Important modeling parameters}

247 Based on the $\mathrm{CO}_{2}$ solubility model developed by Duan and Sun (Duan and Sun, 2003), the 248 concentration of dissolved $\mathrm{CO}_{2}$ in brine under given exposure conditions was $0.689 \mathrm{~mol} / \mathrm{kg}$, 249 partial pressure of $\mathrm{CO}_{2}$ (discounting for water vapor) was 237.4 bar, and fugacity of $\mathrm{CO}_{2}$ was 250122.9 bar. The fugacity of $\mathrm{CO}_{2}$ equals to fugacity coefficient of $\mathrm{CO}_{2} \times \mathrm{CO}_{2}$ partial pressure. 251 Fugacity coefficient of $\mathrm{CO}_{2}$ is from a look-up table based on the equation of state in Duan et al. 252 (2003), and the equation of state is described in SI. Based on CrunchFlow calculation, the brine $253 \mathrm{pH}$ was 4.13 , given a dissolved $\mathrm{CO}_{2}$ concentration of $0.689 \mathrm{~mol} / \mathrm{kg}$. The effective diffusivity 254 exponent $(m)$ was 2.0. $m$ is used to calculate effective diffusivity in porous media from molecular 255 diffusivity. The correlation between effective diffusivity and molecular diffusivity is:

$$
D_{e}=D_{0} \Phi^{m}
$$

257 where $D_{e}$ is effective diffusivity, $D_{0}$ is molecular diffusivity (a property of the diffusing specie), $258 \Phi$ is porosity of the rock matrix, and $m$ is the effective diffusivity exponent of the rock matrix.

259 The exponent $m$ varies between 1.3 and 2.0 for brine-saturated rocks (Bruggeman, 1935; Archie, 260 1942; Adler et al., 1992; Grathwohl, 1992; Shimamura, 1992). In this study, an $m$ value of 2.0 is

261 chosen, which produces permeability result that is consistent with laboratory-measured 262 permeability (see SI for details).

263 Table 2 shows the mineral composition of the unreacted Mount Simon sandstone, and Table 3

264 shows equilibrium constants of the reactions involved in the model, and reaction rate constants 
265 and $\prod_{i=1}^{N} a_{i}^{p_{i}}$ values that are used for the model. Specific surface areas and molar volumes of 266 minerals involved in the model can be found in Table 2. It is important to note that there is no 267 calcite in unreacted Mount Simon sandstone sample to buffer the $\mathrm{pH}$.

\subsection{Sensitivity analysis}

270 A sensitivity analysis was conducted to assess how changes of the modeling parameters affect

271 the simulation results. Seven modeling parameters (i.e., initial concentration of dissolved $\mathrm{CO}_{2}$, 272 initial porosity of the sandstone, total feldspar content of the sandstone, annite content of the 273 sandstone, equilibrium constant of $\mathrm{SiO}_{2}(\mathrm{am})$ precipitation reaction, precipitation rate constant of

$274 \mathrm{SiO}_{2}(\mathrm{am})$, and exponent $(n)$ in equation 4) were tested. Values tested for each parameter and the 275 justification to test each parameter can be found in Table 4. For each analysis, only one variable 276 was varied from the initial conditions, and all the other variables were maintained the same as 277 the initial conditions.

\section{3. Results}

\subsection{Solution chemistry, porosity, $\mathrm{pH}$ and mineral composition results}

280 Table 5 shows a comparison between model-predicted major element concentrations and

281 laboratory-measured major element concentrations after 180 days of exposure. The

282 concentrations predicted by the model are consistent with measured concentrations.

283 Figure 2 shows the changes of porosity, $\mathrm{pH}$ and volume $\%$ of minerals as a function of the 284 distance away from the external sandstone surface in contact with bulk brine after 180 days of 285 exposure. The porosity of the sandstone in the region close to the surface (Figure 2a) increased 286 with the increase of exposure time, which is mainly attributed to the dissolution of feldspar 
287 (Figure 2c) and quartz (Figure 2d). The porosity of the sandstone in the region next to the high-

288

289

290

291

292

293

294

295

296

297

298

299

300

301

302

303

304

305

306

307

308

309

porosity region decreased with the increase of exposure time, which is primarily attributed to the precipitation of $\mathrm{SiO}_{2}(\mathrm{am})$ (Figure 2j). Precipitation of other minerals (i.e., kaolinite and muscovite/illite) also contributed to the decrease of porosity in this low-porosity region (Figures $2 \mathrm{f}$ and $2 \mathrm{i}$ ). Small amount of siderite (less than $0.07 \%$, see Figure $2 \mathrm{~g}$ ) was predicted to form in the region more than $4 \mathrm{~mm}$ away from the sandstone surface. The very small amount of siderite formed did not contribute much to porosity decrease. After 180 days of exposure, the $\mathrm{pH}$ at the surface of the sample was 4.20 and the interior of the sample ( $5 \mathrm{~mm}$ from the sample surface) had a $\mathrm{pH}$ of 4.38. Both $\mathrm{pH}$ values were higher than the $\mathrm{pH}$ of bulk brine. That is to say, the sandstone sample had moderate $\mathrm{pH}$ buffering capacity, which can be attributed to presence of feldspar in the unreacted rock matrix. As for secondary clay mineral formation, the main clay mineral formed was kaolinite. In summary, dissolution of feldspar is the key reaction to cause porosity decrease in the sandstone sample, because the dissolution of feldspar results in release of $\mathrm{Al}^{3+}(\mathrm{aq})$ and $\mathrm{SiO}_{2}(\mathrm{aq})$, which cause precipitation of $\mathrm{SiO}_{2}(\mathrm{am})$ and kaolinite.

\subsection{Permeability results}

Figure 2a shows that the sandstone sample exposed to $\mathrm{CO}_{2}$-saturated brine for 180 days had a high-porosity zone adjacent to the surface of the sample in contact with bulk brine, and the zone next to the high-porosity zone had much lower porosity. Results in Figure 2 implies that there is a low-porosity and low permeability zone at the edge of the sandstone sample after exposure to $\mathrm{CO}_{2}$-saturated brine, and there is a location that has the lowest porosity and lowest vertical permeability in the low-porosity zone (see Supporting Information for details). In permeability calculation, the vertical permeability of that location is approximately the vertical permeability of the entire sample, because the vertical permeability of the entire sample is determined by the 
313 Figure 3a shows the distribution of porosity in the lowest-permeability location, which represents

314 the permeability of the entire sample. Based on Figure $3 a$ and equations (4) and (5), the overall

315 permeability of this location (approximately the same as the vertical permeability of the entire

316 sample) was calculated. Figure $3 \mathrm{~b}$ shows permeability change of the Mount Simon sandstone

317 sample exposed to $\mathrm{CO}_{2}$-saturated brine for 180 days. Both experimental results (obtained from

318 Soong et al. (2014)) and model simulation results are reported in Figure 3b. The model predicted

319 a decrease of permeability (from $1.60 \mathrm{mD}$ to $1.02 \mathrm{mD}$ ) after 180 days of exposure. This

320 permeability decrease was close to the experimental results (from $1.60 \mathrm{mD}$ to $0.80 \mathrm{mD}$ ) reported

321 by Soong et al. (2014).

\section{$322 \quad 3.3$ Sensitivity analysis results}

323 Figure 4 shows results of sensitivity analysis considering the influence of aqueous $\mathrm{CO}_{2}$

324 concentration (Figure 4a), initial porosity (Figure 4b), feldspar content (Figure 4c), annite

325 content (Figure 4d), $K_{e q}\left(\mathrm{SiO}_{2}(\mathrm{am})\right)$ (Figure 4e), $k\left(\mathrm{SiO}_{2}(\mathrm{am})\right)$ (Figure $\left.4 \mathrm{f}\right)$, and exponent $n$ for

326 permeability calculation (Figure $4 \mathrm{~g}$ ). An increase in aqueous $\mathrm{CO}_{2}$ concentration resulted in slight

327 increase of permeability, because an increase in aqueous $\mathrm{CO}_{2}$ concentration decreases $\mathrm{pH}$, which

328 favors mineral dissolution. When initial porosity was low (5\%), the permeability was increased

329 instead of decrease after exposure, because the porosity increase in the high-porosity zone was

330 relatively high given low initial porosity and the permeability increase of the high-porosity zone

331 overcomes the permeability decrease of the low-porosity zone, which contributes to an overall 
332 permeability increase. When initial porosity was very high, the permeability was less decreased

333 compared with the base case after exposure. The permeability of the sample decreased from 1.6

$334 \mathrm{mD}$ to $1.26 \mathrm{mD}$ after 180 days of exposure if the initial porosity of the sample was $30 \%$, while

335 the permeability of the sample decreased from $1.6 \mathrm{mD}$ to $1.02 \mathrm{mD}$ after 180 days of exposure if

336 the initial porosity was $7.9 \%$. Those results can be explained as: less initial pore space means that

337 the pore space is more readily filled with precipitates, and the corresponding permeability drop

338 will be more significant.

Initial feldspar content, $K_{e q}\left(\mathrm{SiO}_{2}(\mathrm{am})\right)$ and $k\left(\mathrm{SiO}_{2}(\mathrm{am})\right.$ had a big impact on the modeled

341 permeability change of the sandstone, because these parameters are directly correlated with how

342 much and how fast $\mathrm{SiO}_{2}(\mathrm{am})$ can precipitate. An increase of initial annite content resulted in an

343 increase of permeability after exposure. The reason is: annite dissolves fast given a low $\mathrm{pH}$ and

344 annite dissolution causes significant porosity and permeability increase of the high-porosity zone.

345 Though a higher initial annite content provides more $\mathrm{Fe}^{2+}$ and enables more precipitation of

346 siderite in the low-porosity zone, the permeability increase of the high-porosity zone still

347 overcomes the permeability decrease of the low-porosity zone, which contributes to an overall

348 permeability increase. The change of exponent $(n)$ for permeability calculation had a moderate

349 impact on permeability result after exposure.

\subsection{Long-term permeability and porosity change}

352 Figure 5a shows model-predicted permeability changes of the Mount Simon sandstone sample 353 exposed to $\mathrm{CO}_{2}$-saturated brine for 5 days, 180 days and 30 years. After 30 years of exposure, 354 the modeled permeability of the sample dropped to $0.003 \mathrm{mD}$, which is mainly attributed to the 
355 occupation of pore space in the region about $0.2 \mathrm{~mm}$ from the sample surface (Figure $5 \mathrm{~b}$ ). The

356 pore space occupation was primarily due to precipitation of $\mathrm{SiO}_{2}(\mathrm{am})$ and kaolinite in the region.

357 Compared with the scenario with 180 days of exposure, much more $\mathrm{SiO}_{2}(\mathrm{am})$ and kaolinite is

358 formed in the low-porosity zone after 30 years of exposure. The excessive precipitation of $\mathrm{SiO}_{2}$

359 (am) and kaolinite causes significant porosity decrease of the low-porosity zone, which

360 contributes to a significant permeability decrease of the entire sample after 30 years of exposure.

\section{Discussion}

363 The model predicts $\mathrm{SiO}_{2}(\mathrm{am})$ and kaolinite formation as a result of interaction between 364 sandstone and $\mathrm{CO}_{2}$-saturated brine after 180 days of exposure, and the formation of $\mathrm{SiO}_{2}(\mathrm{am})$ 365 and kaolinite is the primary cause of porosity and permeability drop of the sandstone. Formation 366 of $\mathrm{SiO}_{2}(\mathrm{am})$ and kaolinite in the pore space of feldspar-bearing sandstone under $\mathrm{CO}_{2}$

367 sequestration conditions has been suggested by several modeling and experimental studies (Gaus 368 et al., 2005; Lagneau et al., 2005; Fu et al., 2009; Shao et al., 2010; Carroll et al., 2012). Though 369 the initial brine compositions, pressure and temperature applied in aforementioned references 370 may differ from the conditions applied in this study, the results in aforementioned references 371 demonstrate that precipitation of $\mathrm{SiO}_{2}(\mathrm{am})$ and kaolinite can be observed in a broad range of $372 \mathrm{CO}_{2}$ sequestration conditions, so $\mathrm{SiO}_{2}(\mathrm{am})$ and kaolinite precipitation should be considered 373 when our model is set up. The formation of $\mathrm{SiO}_{2}(\mathrm{am})$ requires abundant $\mathrm{SiO}_{2}(\mathrm{aq})$ and the 374 formation of kaolinite requires abundant $\mathrm{SiO}_{2}(\mathrm{aq})$ and $\mathrm{Al}$ (III) (aq). $\mathrm{SiO}_{2}$ (aq) mainly comes 375 from dissolution of feldspar and quartz, and $\mathrm{Al}$ (III) (aq) mainly comes from dissolution of 376 feldspar. 
378 The model also predicts formation of very small amount of muscovite/illite. Precipitation of 379 muscovite/illite is possible given large content of K-bearing feldspar in the sample and pore380 filling due to muscovite/illite precipitation under $\mathrm{CO}_{2}$ sequestration conditions has been reported 381 before (Johnson et al., 2004; Fu et al., 2009). If a different geochemical model that predicts 382 significant precipitation of muscovite/illite is applied, the porosity and permeability of the 383 sample might be reduced more after exposure because muscovite/illite has a larger molar volume $384\left(144.5 \mathrm{~cm}^{3} / \mathrm{mol}\right)$ than kaolinite $\left(99.3 \mathrm{~cm}^{3} / \mathrm{mol}\right)$ and $\mathrm{SiO}_{2}(\mathrm{am})\left(22.7 \mathrm{~cm}^{3} / \mathrm{mol}\right)$. Another 385 possibility is montmorillinite $\left(\mathrm{Ca}_{0.165} \mathrm{Mg}_{0.33} \mathrm{Al}_{1.67} \mathrm{Si}_{4} \mathrm{O}_{10}(\mathrm{OH})_{2}\right)$ precipitation. Pore-filling due to 386 montmorillinite precipitation under $\mathrm{CO}_{2}$ sequestration conditions is suggested by Carroll et al. 387 (2012) and Beyer et al. (2012). If a different geochemical model that predicts significant 388 precipitation of montmorillinite is applied, the porosity and permeability of the sample might be 389 reduced more after exposure because montmorillinite has a larger molar volume $\left(155.8 \mathrm{~cm}^{3} / \mathrm{mol}\right)$ 390 than kaolinite and $\mathrm{SiO}_{2}(\mathrm{am})$.

392 Though abundant $\mathrm{CO}_{2}(\mathrm{aq})$ is present in the sandstone- $\mathrm{CO}_{2}$-brine system, the model predicts no 393 formation of Ca-bearing carbonate mineral species (e.g., calcite and dolomite), which is 394 consistent with previous modeling studies and experimental observations (Johnson et al., 2004; 395 Carroll et al., 2012; Soong et al., 2014). That is to say, no or very small amount of Ca-bearing 396 carbonate species will be formed in the host rock (given several months of exposure period) if $397 \mathrm{CO}_{2}$ is injected into the Illinois Basin, from which the Mount Simon sandstone samples were 398 taken. Ca-bearing carbonate species may form at the surface of the sandstone in contact with the 
399 bulk brine as a transient product, but the low $\mathrm{pH}$ at the surface (around 4.1) will finally dissolve 400 any Ca-bearing carbonate species that are formed.

403 Other than $\mathrm{SiO}_{2}(\mathrm{am})$ and kaolinite formation, two other factors that are not considered in the 404 model (fine particle migration and dawsonite $\left(\mathrm{NaAlCO}_{3}(\mathrm{OH})_{2}\right)$ precipitation) may be considered 405 as possible cause of the observed decrease of porosity and permeability of the sandstone sample 406 after 180 days of exposure. The dissolution of minerals at the sandstone surface could result in 407 breakdown of the structural integrity of the sandstone matrix and release of fine sandstone 408 particles. The fine particles released may migrate in the direction of decreasing pressure and 409 deposit in the region next to the high-porosity zone at the surface, thereby blocking those pore 410 spaces and reducing the porosity in the region adjacent to the high-porosity zone. As for 411 dawsonite precipitation, many modeling studies in the past have suggested that the precipitation 412 of dawsonite is possible under $\mathrm{CO}_{2}$ sequestration conditions (e.g., Xu et al., 2004; Johnson et al., 413 2004; Xu et al., 2005; Knauss et al., 2005; White et al., 2005; Audigane et al., 2007; Liu et al., 414 2011). The sandstone sample contains 13.8 vol\% feldspar and the brine in contact with the 415 sandstone sample contains $1.80 \mathrm{~m} \mathrm{Na}^{+}$, which implies that $\mathrm{Al}$ and $\mathrm{Na}$ sources are abundant for 416 dawsonite precipitation. Though dawsonite precipitation under $\mathrm{CO}_{2}$ sequestration conditions is 417 thermodynamically favorable, it has not been observed in experimental studies and the reliability 418 of the equilibrium constant for dawsonite precipitation reaction used in past modeling studies has 419 been challenged (Kaszuba et al., 2011). It is, therefore, believed to be unlikely that dawsonite 
420 formation will proceed to an appreciable extent and, therefore, unlikely that this would be the

421 cause of observed reductions in Mount Simon sandstone permeability (Soong et al., 2014).

423 The porosity of the Mount Simon sample used in this study is $7.9 \%$. This porosity is quite low

424 and is not representative of the porosity of typical $\mathrm{CO}_{2}$ storage formations (14\% to $35 \%$,

425 Rochelle et al., 2004; Johnson et al., 2004; Hovorka et al., 2006). However, given the highly

426 variable porosity and permeability of the Mount Simon formation, there is a potential for $\mathrm{CO}_{2}$

427 plume and $\mathrm{CO}_{2}$-saturated brine to migrate from the storage region of Mount Simon to

428 surrounding regions with low porosity, which is the scenario of this study. The results presented

429 in this manuscript show that if the regions surrounding the storage region have a porosity of $\sim 8 \%$,

430 there will be a significant reduction of permeability and that will be beneficial for $\mathrm{CO}_{2}$

431 containment. The model predicts a significant porosity and permeability reduction of the

432 sandstone after 30 years of exposure, which implies that the $\mathrm{CO}_{2}$ injected into the Mount Simon

433 formation can be securely retained. Specifically, after the period of active injection, $\mathrm{CO}_{2}$ -

434 saturated brine would be relatively static and the formation of $\mathrm{SiO}_{2}(\mathrm{am})$ and kaolinite could 435 proceed to a significant extent. The formation of a $\mathrm{SiO}_{2}(\mathrm{am})$ and kaolinite -rich layer with low

436 porosity and permeability would act as a barrier to impede further lateral migration of both free-

437 phase $\mathrm{CO}_{2}$ plume and $\mathrm{CO}_{2}$-saturated brine. As such, the formation of $\mathrm{SiO}_{2}(\mathrm{am})$ and kaolinite in

438 formations with the attributes described herein could have advantages for improved storage

439 security. For the storage region of Mount Simon with a typical porosity of $30 \%$, the effect of

$440 \quad \mathrm{SiO}_{2}(\mathrm{am})$ and kaolinite precipitation has a smaller impact on the permeability (21\% permeability

441 reduction, see Figure $4 \mathrm{~b}$ ). Therefore, the chemical reactions between sandstone and $\mathrm{CO}_{2}-$ 
442 saturated brine may have a small impact on the injectivity of the $\mathrm{CO}_{2}$ storage intervals with high

443 porosity and permeability.

\section{Conclusions}

Permeability decrease of Mount Simon sandstone samples after 180 days of exposure to $\mathrm{CO}_{2}$ -

447 saturated brine is reproduced by a numerical model with the use of reactive transport code

448 CrunchFlow. The measured permeability results show a permeability drop of Mount Simon

449 sandstone samples from $1.60 \mathrm{mD}$ to $0.80 \mathrm{mD}$ after 180 days of exposure, while the model

450 predicts a permeability decrease from $1.60 \mathrm{mD}$ to $1.02 \mathrm{mD}$ after 180 days of exposure. The

451 model predicts that $\mathrm{SiO}_{2}(\mathrm{am})$ and kaolinite are the primary minerals that cause permeability

452 decrease, followed by the precipitation of muscovite/illite.

454 Based on sensitivity analysis results, initial porosity, initial feldspar content and precipitation rate

455 constant of $\mathrm{SiO}_{2}(\mathrm{am})$ are the three most important variables that affect permeability change.

456 Permeability change is very sensitive to initial porosity because initial porosity is an important

457 parameter in eqn. 4 to calculate permeability change. The most significant permeability decrease

458 occurs when the initial porosity is between $6 \%$ and $10 \%$. Permeability may increase instead of

459 decrease when the initial porosity is small (less than 5\%). Permeability change is sensitive to

460 initial feldspar content because feldspar is the source of $\mathrm{Si}$ and $\mathrm{Al}$ for $\mathrm{SiO}_{2}(\mathrm{am})$ and kaolinite

461 precipitation. An increase of feldspar content results in decrease of permeability because more

$462 \mathrm{SiO}_{2}$ (aq) and $\mathrm{Al}$ (III) (aq) can be provided by feldspar to form $\mathrm{SiO}_{2}$ (am) and kaolinite.

463 Permeability change is also sensitive to precipitation rate constant of $\mathrm{SiO}_{2}$ (am) because the rate 
464 constant is used in eqn. 3 to calculate how fast $\mathrm{SiO}_{2}(\mathrm{am})$ can precipitate. An increase of the

465 precipitation rate constant of $\mathrm{SiO}_{2}(\mathrm{am})$ from $10^{-7.09} \mathrm{~mol} /\left(\mathrm{m}^{2} \mathrm{~s}\right)$ to $10^{-6.09} \mathrm{~mol} /\left(\mathrm{m}^{2} \mathrm{~s}\right)$ results in the

466 post-exposure permeability to drop from $1.02 \mathrm{mD}$ to $0.46 \mathrm{mD}$. After 30 years of exposure, the

467 permeability of sandstone is predicted to drop from $1.6 \mathrm{mD}$ to $0.003 \mathrm{mD}$. In summary, if the

468 sandstone surrounding the $\mathrm{CO}_{2}$ storage formation has a porosity between $6 \%$ and $10 \%$ and is rich

469 in feldspar, the $\mathrm{CO}_{2}$ injected into the storage formation may be securely retained due to the

470 permeability reduction of surrounding sandstone.

471

472 Acknowledgments

473 This work was completed as part of National Energy Technology Laboratory (NETL) research

474 for the Department of Energy's Research and Development Program under Section 999 of the

475 Energy Policy Act of 2005. The authors would like to thank the Office of Research and

476 Development at NETL for funding support and providing access to research article databases,

477 computing devices, etc. The authors also would like to thank Bret Howard at NETL Pittsburgh

478 site for SEM and XRD analyses on Mount Simon sandstone samples used in our study.

480 References

481 Adler, P.M., Jacquin, C.G., Thovert, J.F., 1992. The formation factor of reconstructed porous 482 media. Water Res. Res., 28 (6), 1571-1576.

483 Andreani, M., Luquot, L., Gouze, P., Godard, M., Hoise, E., \& Gibert, B., 2009. Experimental 484 study of carbon sequestration reactions controlled by the percolation of $\mathrm{CO}_{2}$-rich brine through 485 peridotites. Environ. Sci. Technol., 43(4), 1226-1231.

486 Archie, G.E., (1942. The electrical resistivity log as an aid in determining some reservoir 487 characteristics. Trans. AIME, 146, 54-62. 
Audigane, P., Gaus, I., Czernichowski-Lauriol, I., Pruess, K., Xu, T., 2007. Two dimensional reactive transport modeling of $\mathrm{CO}_{2}$ injection in a saline aquifer at the Sleipner Site, North Sea. Am. J. Sci. 307, 974-1008.

Balashov, V. N., Guthrie, G. D., J. Hakala, A. J., Lopano, C. L., Rimstidt, D. J., and Brantley, S. L., 2013. Predictive modeling of $\mathrm{CO}_{2}$ sequestration in deep saline sandstone reservoirs: Impacts of geochemical kinetics. Appl. Geochem. 30, 41-56.

Barlet-Gouédard, V., Rimmelé, G., Goffé, B. and Porcherie, O., 2007. Well Technologies for $\mathrm{CO}_{2}$ Geological Storage: $\mathrm{CO}_{2}$-Resistant Cement. Oil Gas Sci. Technol., 62 (3), 325-334.

Baur, I., Keller, P., Mavrocordatos, D., Wehrli, B., and Johnson, C. A., 2004. Dissolutionprecipitation behaviour of ettringite, monosulfate, and calcium silicate hydrate. Cement Concrete Res., 34(2), 341-348.

Beyer, C., Li, D., De Lucia, M., Kühn, M., \& Bauer, S., 2012. Modelling $\mathrm{CO}_{2}$-induced fluidrock interactions in the Altensalzwedel gas reservoir. Part II: coupled reactive transport simulation. Environmental Earth Sciences, 67(2), 573-588.

Bibi, I., Singh, B. and Silvester, E., 2011. Dissolution of illite in saline-acidic solutions at $25{ }^{\circ} \mathrm{C}$. Geochim. Cosmochim. Ac., 75(11), 3237-3249.

Brgm, 2011. THERMODDEM: A thermodynamic database for modeling the alteration of wastes minerals. Available at: http://thermoddem.brgm.fr/index.asp?langue=GB . Last accessed: 02/20/2014.

Bruggeman, D.A.G., 1935. Berechnung verschiedener physikalischer Konstanten von heterogenen Substanzen. Ann. Phys., 24, 636-664.

Brunet, J. P. L., Li, L., Karpyn, Z. T., Kutchko, B. G., Strazisar, B. and Bromhal, G., 2013. Dynamic evolution of cement composition and transport properties under conditions relevant to geological carbon sequestration. Energ. Fuel., 27(8), 4208-4220.

Caseri, W. R., Shelden, R. A. and Suter, U. W., 1992. Preparation of muscovite with ultrahigh specific surface area by chemical cleavage. Colloid Polym. Sci., 270(4), 392-398.

Casey, W.H., Westrich, H.R., Holdren, G.R., 1991. Dissolution rates of plagioclase at pH = 2 and 3. Am. Mineral, 76, 1-2.

Carroll, S. A., \& Walther, J. V., 1990. Kaolinite dissolution at 25, 60, and $80{ }^{\circ}$ C. Am. J. Sci, 290(7), 797-810.

Carroll, S. A., McNab, W. W., Dai, Z., and Torres, S. C., 2012. Reactivity of Mount Simon sandstone and the Eau Claire Shale under $\mathrm{CO}_{2}$ storage conditions. Environ. Sci. Technol., 47(1), 252-261. 
521 Craft, B. C., Hawkins, M. F., Terry, R. E., 1991. Applied Petroleum Reservoir Engineering.

522 Prentice Hall, Englewood Cliffs, NJ, p 431.

523 Crandell, L. E., Ellis, B. R. and Peters, C. A., 2009. Dissolution potential of $\mathrm{SO}_{2}$ co-injected with

$524 \mathrm{CO}_{2}$ in geologic sequestration. Environ. Sci. Technol., 44(1), 349-355.

525 Computer Support Group, Inc., 2014. Water Density Calculator. Available at:

526 http://www.csgnetwork.com/h2odenscalc.html. Last accessed: 05/23/2014.

527 Duan, Z. H. and Sun, R., 2003. An improved model calculating $\mathrm{CO}_{2}$ solubility in pure water and 528 aqueous $\mathrm{NaCl}$ solutions from 273 to $533 \mathrm{~K}$ and from 0 to 2000 bar. Chem. Geol., 193(3), 257 529271.

530 Fu, Q., Lu P., Konishi, H., Dilmore, R., Xu, H., Seyfried, W. Zhu, C., 2009. Coupled alkali531 feldspar dissolution and secondary mineral precipitation in batch systems: 1 . New experiments at $532200^{\circ} \mathrm{C}$ and 300 bars. Chem. Geol., 258, 125-135.

533 Garcia, S., Rosenbauer, R. J., Palandri, J., \& Mercedes Maroto-Valer, M., 2011. Experimental 534 and simulation studies of iron oxides for geochemical fixation of $\mathrm{CO}_{2}-\mathrm{SO}_{2}$ gas mixtures. Energ. 535 Procedia, 4, 5108-5113.

536 Gasda, S. E., Nordbotten, J. M. and Celia, M. A., 2008. Determining effective wellbore 537 permeability from a field pressure test: a numerical analysis of detection limits. Environ. Geol., $538 \quad 54,1207-1215$.

539 Gaus, I., Azaroual, M. and Czernichowski-Lauriol, I., 2005. Reactive transport modelling of the 540 impact of $\mathrm{CO}_{2}$ injection on the clayey cap rock at Sleipner (North Sea). Chem. Geol., 217(3), 541 319-337.

542 Gherardi, F., Audigane, P. and Gaucher, E. C., 2012. Predicting long-term geochemical 543 alteration of wellbore cement in a generic geological $\mathrm{CO}_{2}$ confinement site: Tackling a difficult 544 reactive transport modeling challenge. J. Hydrol., 420, 340-359.

545 Global CCS Institute, 2011. The Global Status of CCS: 2011. Global CCS Institute, Canberra, 546 Australia, ISBN 978-0-9871863-0-0.

547 Grathwohl, P., 1992. Diffusion controlled desorption of organic contaminants in various soils 548 and rocks. 7th International Symposium on Water Rock Interactions, 1992, Park City, Utah, 549 USA.

550 Gunter, W. D., Wiwehar, B. and Perkins, E. H., 1997. Aquifer disposal of $\mathrm{CO}_{2}$-rich greenhouse 551 gases: extension of the time scale of experiment for $\mathrm{CO}_{2}$-sequestering reactions by geochemical 552 modelling. Mineral. Petrol., 59(1-2), 121-140. 
553 Holloway, S., 1997. An overview of the underground disposal of carbon dioxide. Energ. Convers.

554 Manage., 38, 193-198.

555 Hovorka, S. D., Benson, S. M., Doughty, C., Freifeld, B. M., Sakurai, S., Daley, T. M., Kharaka, 556 Y. K., Holtz, M. H., Trautz, R. C., Nance, H. S., Myer, L. R. and Knauss, K. G., 2006.

557 Measuring permanence of $\mathrm{CO}_{2}$ storage in saline formations: the Frio experiment. Environmental

558 Geosciences, 13(2), 105-121.

559 Jeong, H. S. and Pecha, D. L., 2011. Pipelines 2011: A Sound Conduit for Sharing Solutions.

560 ASCE Publications, Reston, VA.

561 Johnson, J. W., Nitao, J. J., and Knauss, K. G., 2004. Reactive transport modelling of $\mathrm{CO}_{2}$

562 storage in saline aquifers to elucidate fundamental processes, trapping mechanisms, and

563 sequestration partitioning. Lawrence Livermore National Laboratory report, UCRL-JRNL-

564205627.

565 Johnson, J.W., Nitao, J.J., Morris, J.P., 2005. Modeling the long-term isolation performance of 566 natural and engineered geologic $\mathrm{CO}_{2}$ storage sites. Greenh. Gas Con. Technol., 9, 1315-1321.

567 Johnson, J. W., Nitao, J. J., \& Morris, J. P., 2005b. Reactive transport modeling of cap rock 568 integrity during natural and engineered $\mathrm{CO}_{2}$ storage. Carbon Dioxide Capture for Storage in 569 Deep Geologic Formations, Volume 2, Elsevier Ltd., Oxford, UK.

570 Karamalidis, A. K., Torres, S. G., Hakala, J. A., Shao, H., Cantrell, K. J., \& Carroll, S., 2012.

571 Trace metal source terms in carbon sequestration environments. Environmental science \&

572 technology, 47(1), 322-329

573 Kaszuba, J. P., Janecky, D. R., \& Snow, M. G., 2005. Experimental evaluation of mixed fluid 574 reactions between supercritical carbon dioxide and $\mathrm{NaCl}$ brine: Relevance to the integrity of a 575 geologic carbon repository. Chem. Geol., 217(3), 277-293.

576 Kaszuba, J. P., Viswanathan, H. S., \& Carey, J. W., 2011. Relative stability and significance of 577 dawsonite and aluminum minerals in geologic carbon sequestration. Geophys. Res. Lett., 38(8), 578 L08404.

579 Kharaka, Y. K., Cole, D. R., Thordsen, J. J., Gans, K. D. and R. Burt Thomas, R. B., 2013.

580 Geochemical Monitoring for Potential Environmental Impacts of Geologic Sequestration of $\mathrm{CO}_{2}$. 581 Rev. Mineral. Geochem., 77(1), 399-430.

582 Knauss, K. G., and Wolery, T. J., 1989. Muscovite dissolution kinetics as a function of $\mathrm{pH}$ and 583 time at $70{ }^{\circ} \mathrm{C}$. Geochim. Cosmochim. Ac., 53(7), 1493-1501.

584 Knauss, K.G., Johnson, J.W., Steefel, C.I., 2005. Evaluation of the impact of $\mathrm{CO}_{2}$, 585 cocontaminant gas, aqueous fluid and reservoir rock interactions on the geologic sequestration of $586 \mathrm{CO}_{2}$. Chem. Geol. 217, 339-350. 
Kummerow, J. and Spangenberg, E., 2011. Experimental evaluation of the impact of the interactions of $\mathrm{CO}_{2}-\mathrm{SO}_{2}$, brine, and reservoir rock on petrophysical properties: A case study from the Ketzin test site, Germany. Geochem., Geophy., Geosy.,12(5).

Kumpel, H. (editor), 2003. Thermo-hydro-mechanical coupling in fractured rock. Birkhauser Verlag, Basel, Switzerland.

Lagneau, V., Pipart, A., \& Catalette, H., 2005. Reactive Transport modelling and Long Term Behaviour of $\mathrm{CO}_{2}$ Sequestration in Saline Aquifers. Oil Gas Sci. Technol., 60(2), 231-247.

Lichtner, P.C., 1992. Time-space continuum description of fluid/rock interaction in permeable media. J. Geophys. Res., 3135-3155.

Liu, F., Lu, P., Zhu, C., Xiao, Y., 2011. Coupled reactive flow and transport modeling of $\mathrm{CO}_{2}$ sequestration in the Mt. Simon sandstone formation, midwest USA. Int. J. Greenh. Gas Con. 5, 294-307.

Liu, F., Lu, P., Griffith, C., Hedges, S. W., Soong, Y., Hellevang, H. and Zhu, C., 2012. $\mathrm{CO}_{2^{-}}$ brine-caprock interaction: reactivity experiments on Eau Clair Shale and a review of relevant literature. Int. J. Greenh. Gas Con., 7, 153-167.

Lu, J., Milliken, K., Reed, R. M., \& Hovorka, S., 2011. Diagenesis and sealing capacity of the middle Tuscaloosa mudstone at the Cranfield carbon dioxide injection site, Mississippi, USA. Environmental Geosciences, 18(1), 35-53.

Luquot, L. and Gouze, P., 2009. Experimental determination of porosity and permeability changes induced by injection of $\mathrm{CO}_{2}$ into carbonate rocks. Chem. Geol., 265(1), 148-159.

Luquot, L., Andreani, M., Gouze, P., \& Camps, P., 2012. $\mathrm{CO}_{2}$ percolation experiment through chlorite/zeolite-rich sandstone (Pretty Hill Formation-Otway Basin-Australia). Chemical geology, 294, 75-88.

Marty, N. C. M., Tournassat, C., Burnol, A., Giffaut, E., and Gaucher, E. C., 2009. Influence of reaction kinetics and mesh refinement on the numerical modelling of concrete/clay interactions. J. Hydrol., 364 (1-2), 58-72.

Morris, J. P., McNab, W. W., Carroll, S. K., Hao, Y., Foxall, W., \& Wagoner, J. L., 2009. Injection and reservoir hazard management: the role of injection-induced mechanical deformation and geochemical alteration at In Salah $\mathrm{CO}_{2}$ storage project: status report quarter end, June 2009. LLNL Technical Report, doi: 10.2172/964517.

Oelkers, E. H., Schott, J., Gauthier, J. M. and Herrero-Roncal, T., 2008. An experimental study of the dissolution mechanism and rates of muscovite. Geochim. Cosmochim. Ac., 72(20), 49484961. 
621 Palandri, J. and Kharaka, Y. K., 2004. Compilation of rate parameters of water-mineral 622 interaction kinetics for application to geochemical modeling. In U.S. Geological Survey, Open 623 File Report 2004-1068; U.S. Geological Survey.

624 Palandri, J. L., \& Kharaka, Y. K., 2005. Ferric iron-bearing sediments as a mineral trap for $\mathrm{CO}_{2}$ 625 sequestration: Iron reduction using sulfur-bearing waste gas. Chem. Geol., 217(3), 351-364.

626 Parthasarathy, H., Tasneem, K., Dzombak, D. A., Karamalidis, A., 2011. Arsenic Dissolution 627 from Arsenopyrite Under Carbon Dioxide Geologic Sequestration Conditions. 2011 AGU Fall 628 Meeting, San Francisco, CA, USA.

629 Rochelle, C. A., Czernichowski-Lauriol, I., \& Milodowski, A. E., 2004. The impact of chemical 630 reactions on $\mathrm{CO} 2$ storage in geological formations: a brief review. Geological Society, London, 631 Special Publications, 233(1), 87-106.

632 Sel, O., Radha, A. V., Dideriksen, K., \& Navrotsky, A., 2012. Amorphous iron (II) carbonate: 633 Crystallization energetics and comparison to other carbonate minerals related to $\mathrm{CO}_{2}$ 634 sequestration. Geochim. Cosmochim. Ac., 87, 61-68.

635 Shao, H., Ray, J. R., \& Jun, Y. S., 2010. Dissolution and precipitation of clay minerals under 636 geologic $\mathrm{CO}_{2}$ sequestration conditions: $\mathrm{CO}_{2}-$ brine- phlogopite interactions. Environ. Sci.

637 Technol., 44(15), 5999-6005.

638 Shen, D., Fu, G., Al-Saiari, H. A., Kan, A. T. and Tomson, M. B., 2009. Barite 639 dissolution/precipitation kinetics in porous media and in the presence and absence of a common 640 scale inhibitor. SPE J., 14(03), 462-471.

641 Shimamura, K., 1992. Gas diffusion through compacted sands. Soil Sci., 153 (4), 274-279.

642 Small, J. S., 1993. Experimental determination of the rates of precipitation of authigenic illite 643 and kaolinite in the presence of aqueous oxalate and comparison to the K/Ar ages of authigenic 644 illite in reservoir sandstones. Clay. Clay Mineral., 41, 191-191.

645 Soong, Y., Howard, B. H., Hedges, S. W., Haljasmaa, I., Warzinski, R. P., Gino Irdi, G. and 646 McLendon, T. R., 2014. $\mathrm{CO}_{2}$ sequestration in saline formation. Aerosol Air Qual. Res., 14, 522647532.

648 Steefel, C. I., 2009. CrunchFlow User's Manual. Lawrence Berkeley National Laboratory, 649 Berkeley, CA.

650 Strang, G., 1968. On the construction and comparison of difference schemes, SIAM J. Numer. 651 Anal., 506-517. 
652 The North American Carbon Storage Atlas (NACSA), 2012. NACSA 2012 (1 ${ }^{\text {st }}$ Edition).

653 Available at: http://www.netl.doe.gov/File\%20Library/Research/Carbon-

654 Storage/NACSA2012.pdf.

655 Turcio, M., Reyes, J. M., Camacho, R., Lira-Galeana, C., Vargas, R. O., \& Manero, O., 2013.

656 Calculation of effective permeability for the BMP model in fractal porous media. Journal of

657 Petroleum Science and Engineering, 103, 51-60.

658 Xu, T., Apps, J.A., Pruess, K., 2004. Numerical simulation of $\mathrm{CO}_{2}$ disposal by mineral trapping

659 in deep aquifers. Appl. Geochem. 19, 917-936.

660 Xu, T., Apps, J.A., Pruess, K., 2005. Mineral sequestration of carbon dioxide in a sandstone-

661 shale system. Chem. Geol. 217, 295-318.

$662 \mathrm{Xu}, \mathrm{T} .$, Zheng, L. and Tian, H., 2011. Reactive transport modeling for $\mathrm{CO}_{2}$ geological

663 sequestration. J. Petr. Sci. Eng., 78(3), 765-777.

664 White, S.P., Allis, R.G., Moore, J., Chidsey, T., Morgan, C., Gwynn, W., Adams, M., 2005.

665 Simulation of reactive transport of injected $\mathrm{CO}_{2}$ on the Colorado Plateau, Utah, USA. Chem.

666 Geol. 217, 387-405.

667 White, J. A., Borja, R. I., \& Fredrich, J. T., 2006. Calculating the effective permeability of 668 sandstone with multiscale lattice Boltzmann/finite element simulations. Acta Geotechnica, 1(4), 669 195-209.

670 Wilson, A. M., Sanford, W., Whitaker, F., \& Smart, P., 2001. Spatial patterns of diagenesis 671 during geothermal circulation in carbonate platforms. Am. J. Sci., 301(8), 727-752.

672 Wolery T.J., Jackson, K. J., Bourcier, W. L., Bruton, C. J., Viani, B. E., Knauss, K. G., and 673 Delany, J. M., 1990. Current Status of the EQ3/6 Software Package for Geochemical Modeling. 674 ACS Symposium Series, 416, 104-116.

675 Yong, R. N., Mohaned, A.M.O. and Warkentin, B. P., 1992. Principles of Contaminant Transport 676 in Soils. Elsevier, New York, NY.

677 Yu, Q. L. and Brouwers H. J. H., 2011. Microstructure and mechanical properties of beta678 hemihydrate produced gypsum: An insight from its hydration process. Constr. Build Mater., 25, 679 3149-3157.

680 Zerai, B., Saylor, B. Z., \& Matisoff, G., 2006. Computer simulation of $\mathrm{CO}_{2}$ trapped through 681 mineral precipitation in the Rose Run Sandstone, Ohio. Appl. Geochem., 21(2), 223-240.

682 Zhang, L., Dzombak, D. A., Nakles, D. V., Brunet, J. P. L. and Li, L., 2013. Reactive Transport 683 Modeling of Interactions between Acid Gas $\left(\mathrm{CO}_{2}+\mathrm{H}_{2} \mathrm{~S}\right)$ and Pozzolan-Amended Wellbore 684 Cement under Geologic Carbon Sequestration Conditions. Energ. Fuel., 27(11), 6921-6937. 
685 Zysset, A., Stauffer, F. and Dracos, T., 1994. Modeling of chemically reactive groundwater 686 transport, Water Resources Res., 2217-2228. 

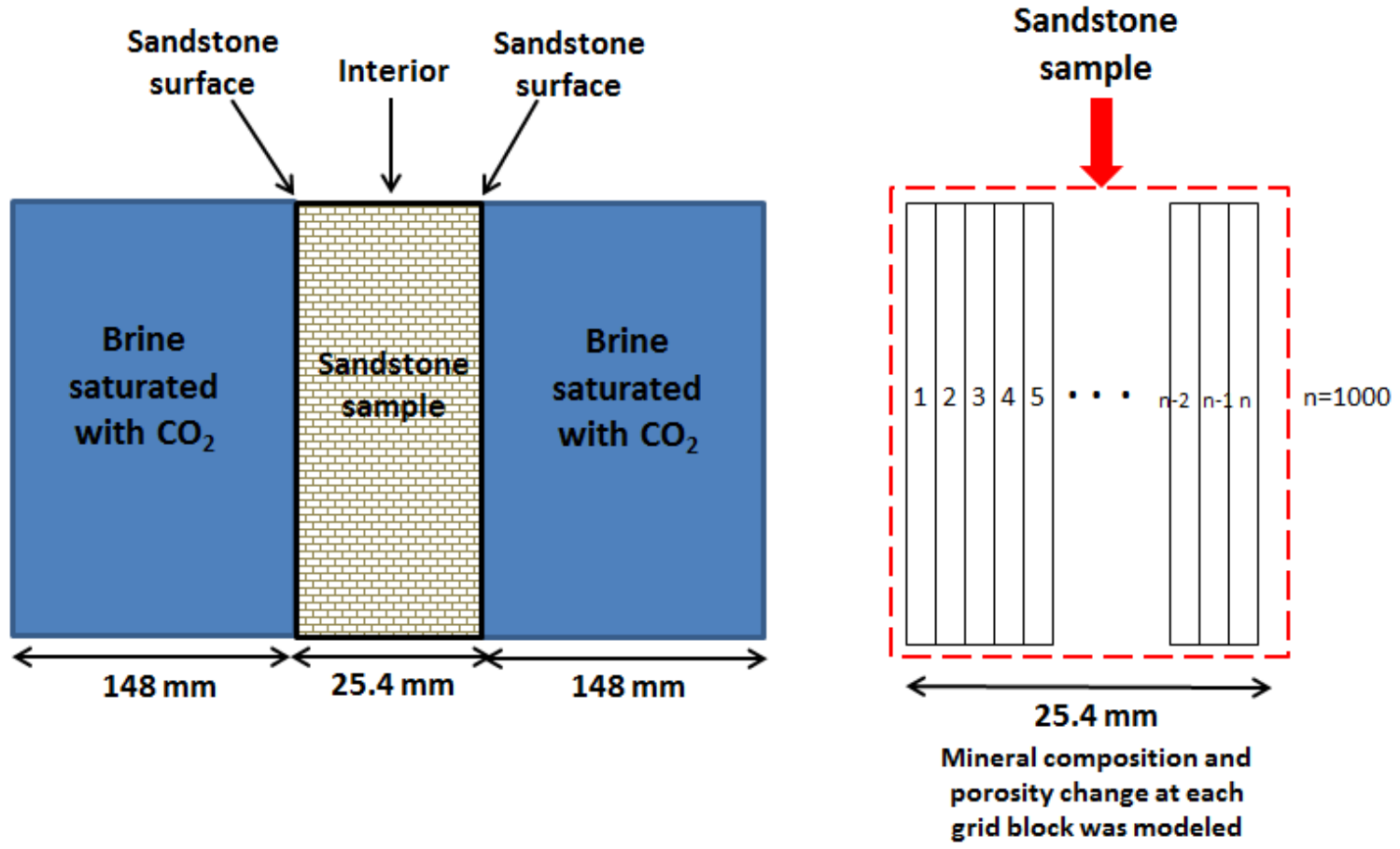

Figure 1: Schematic of the modeling region. 
a)

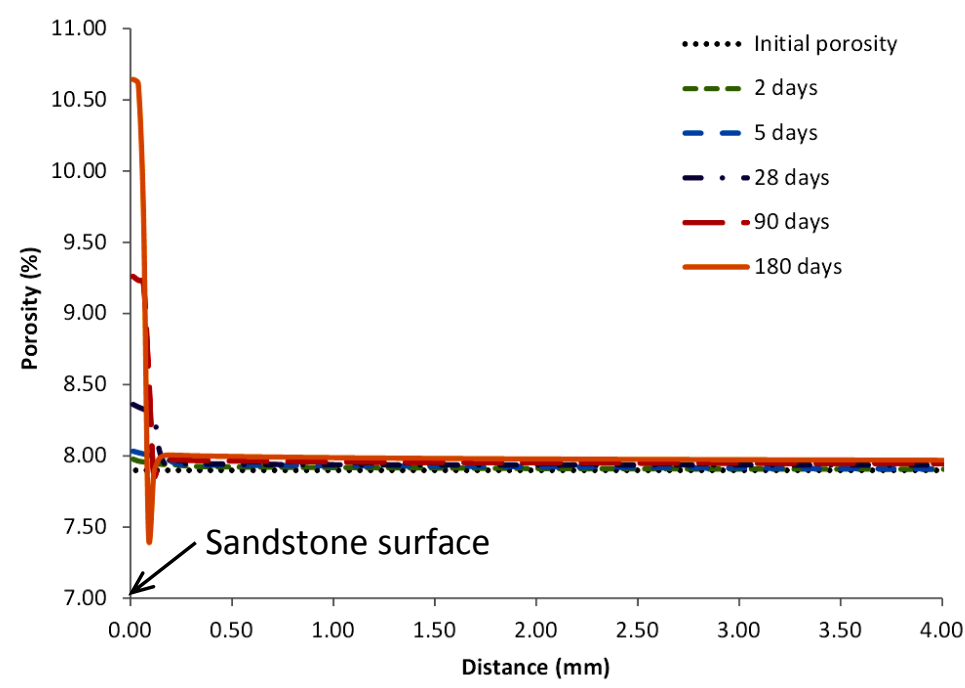

c)

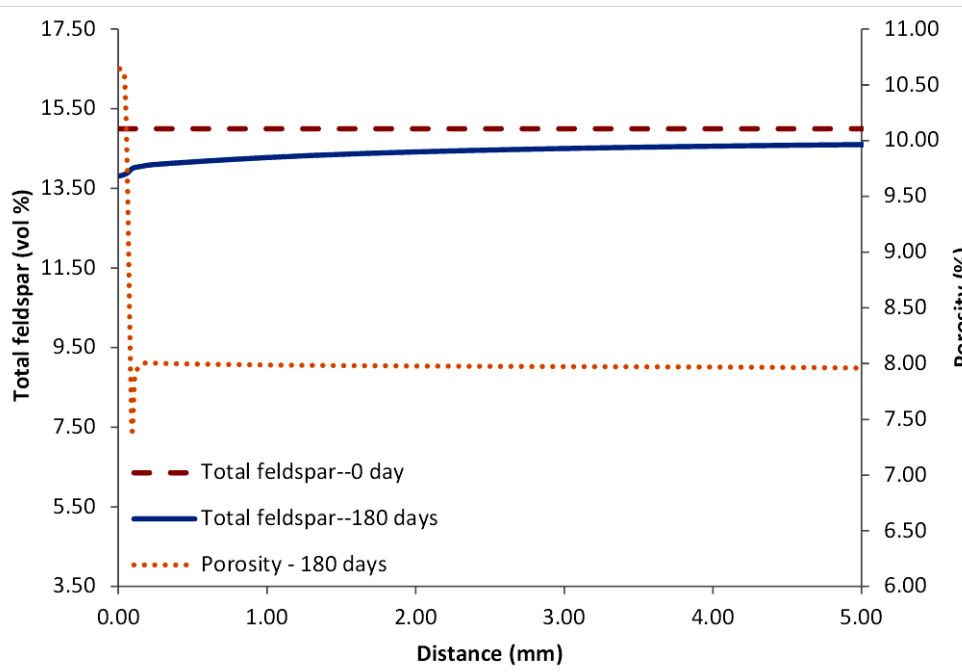

e)

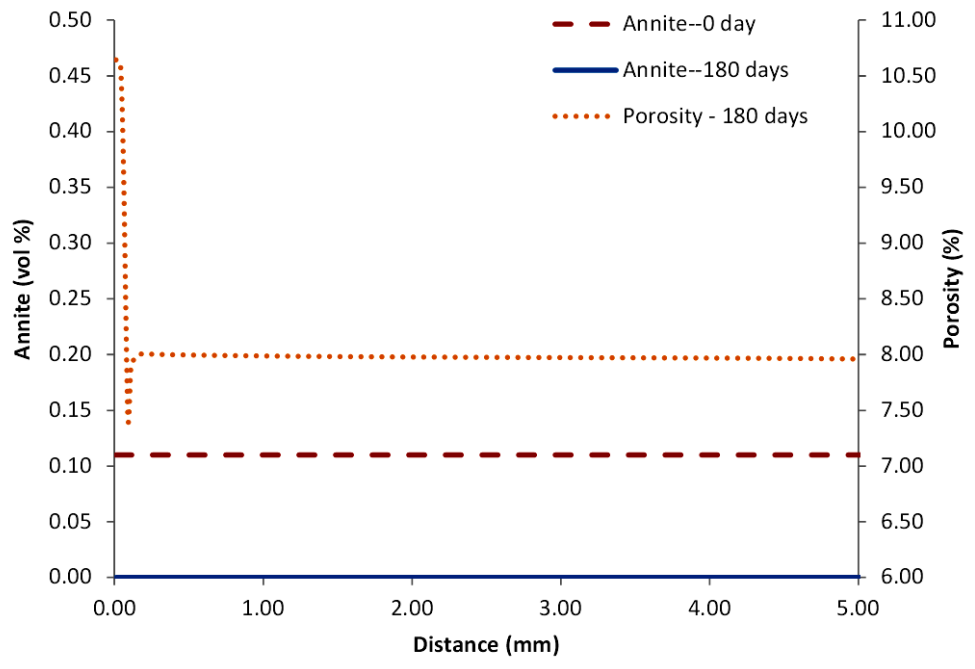

b)

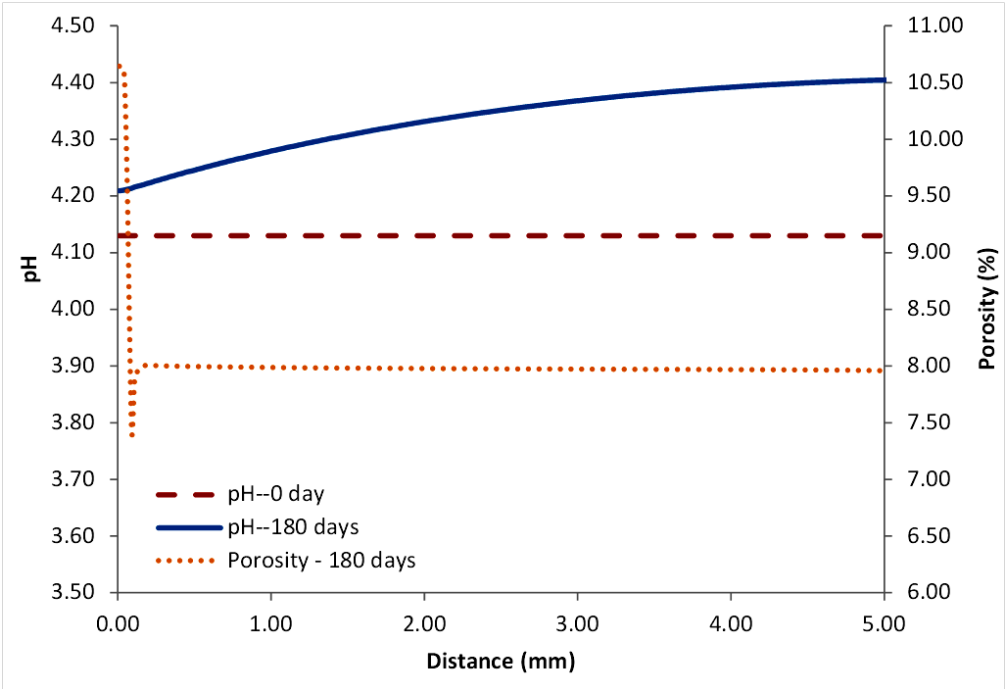

d)

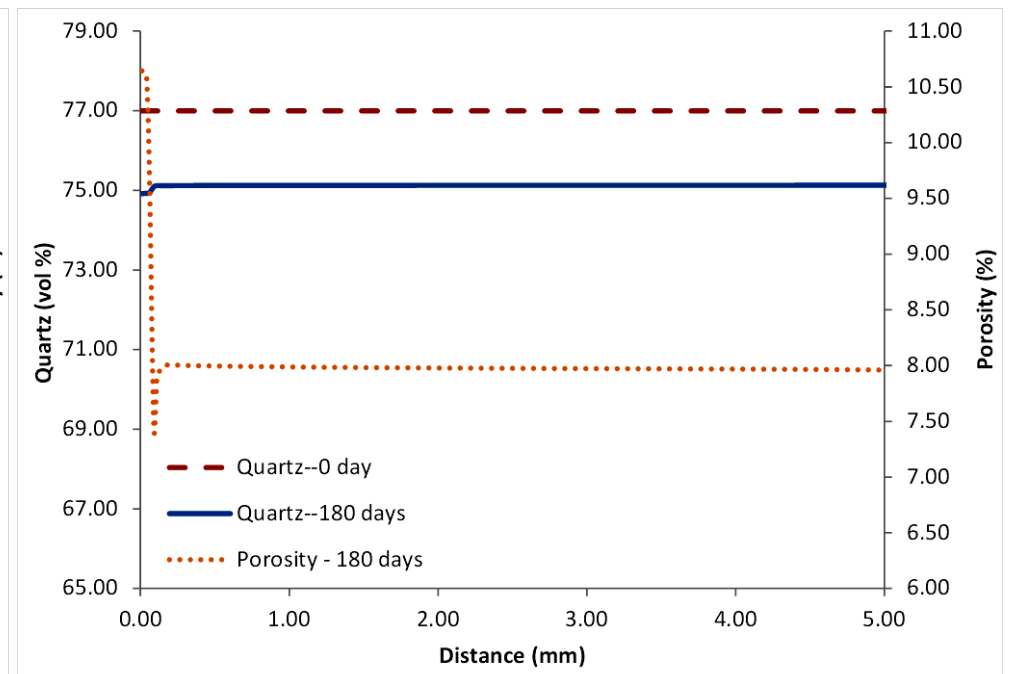

f)

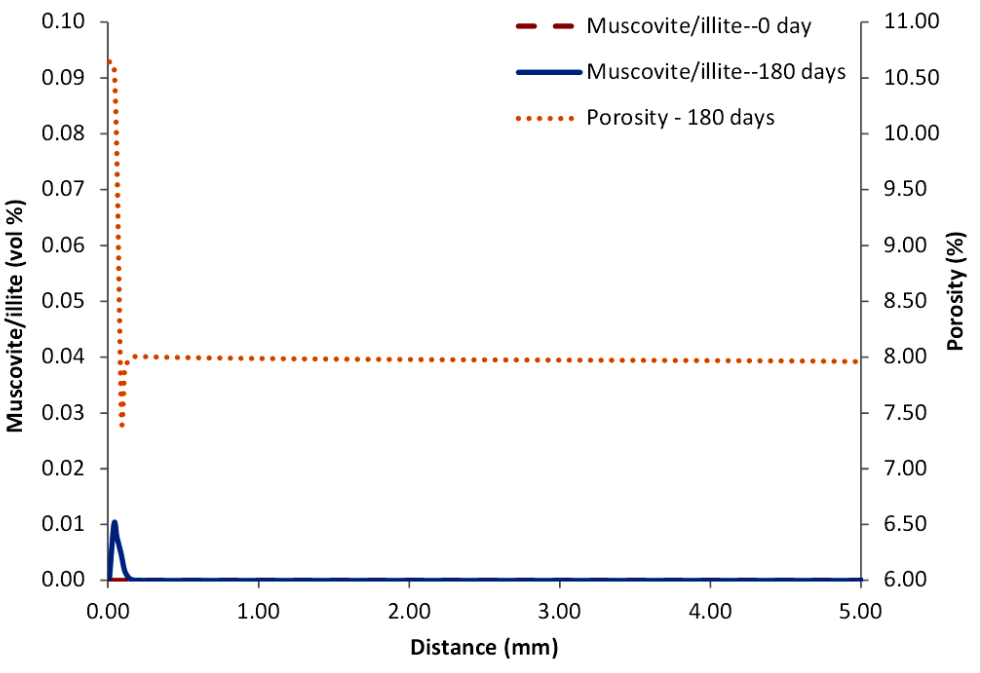


g)
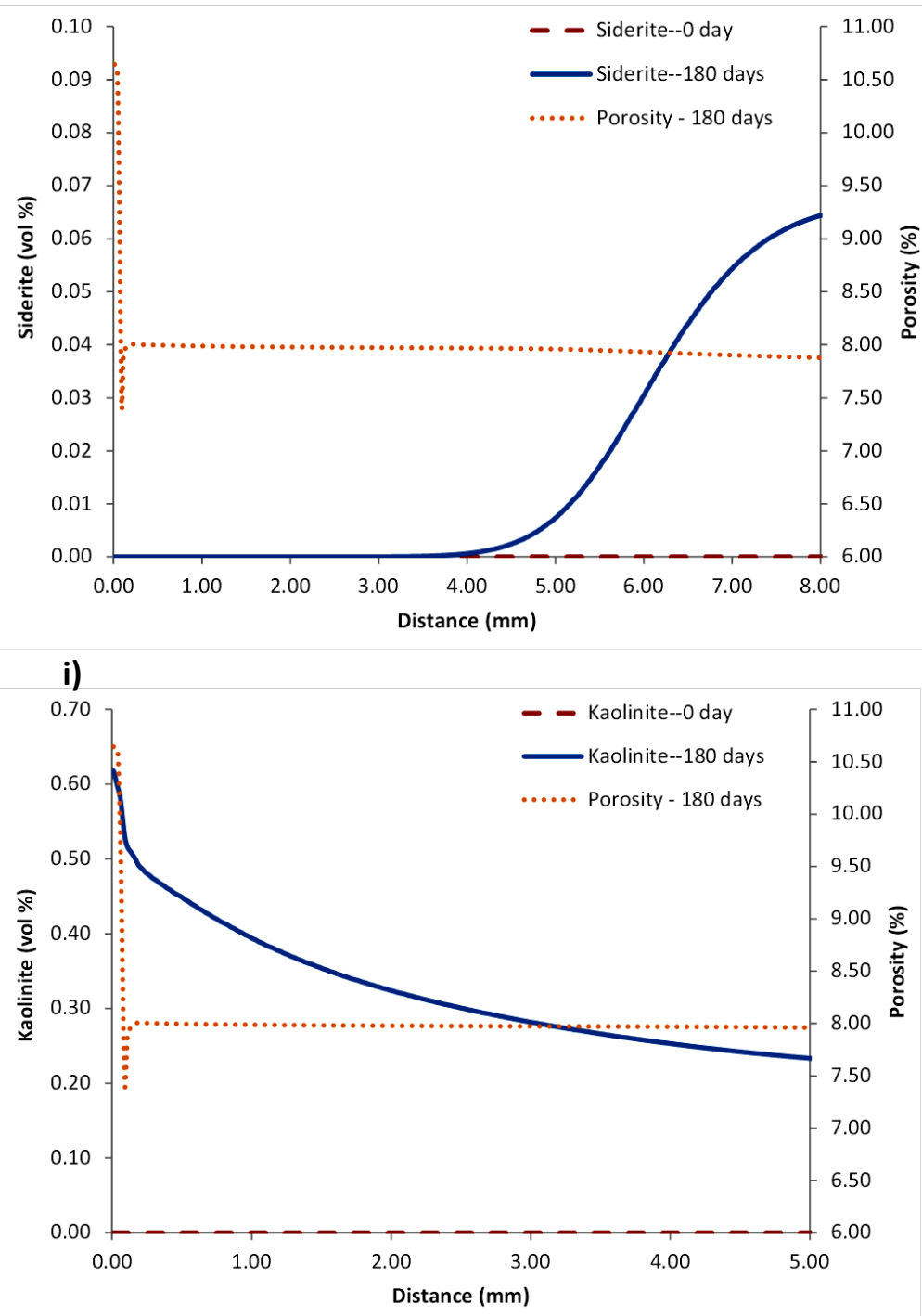

k)

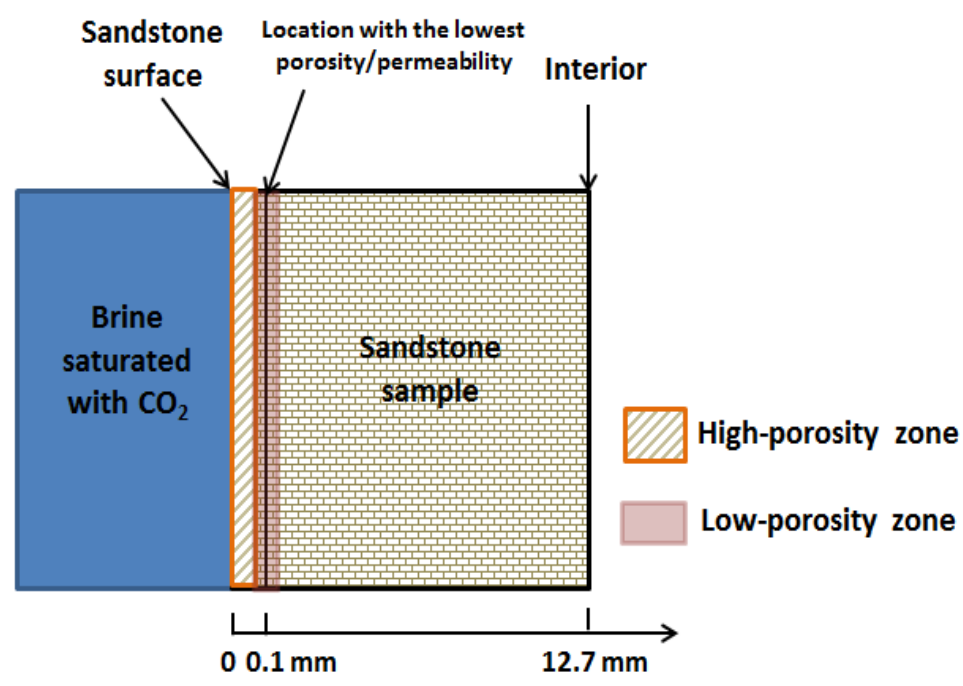

h)
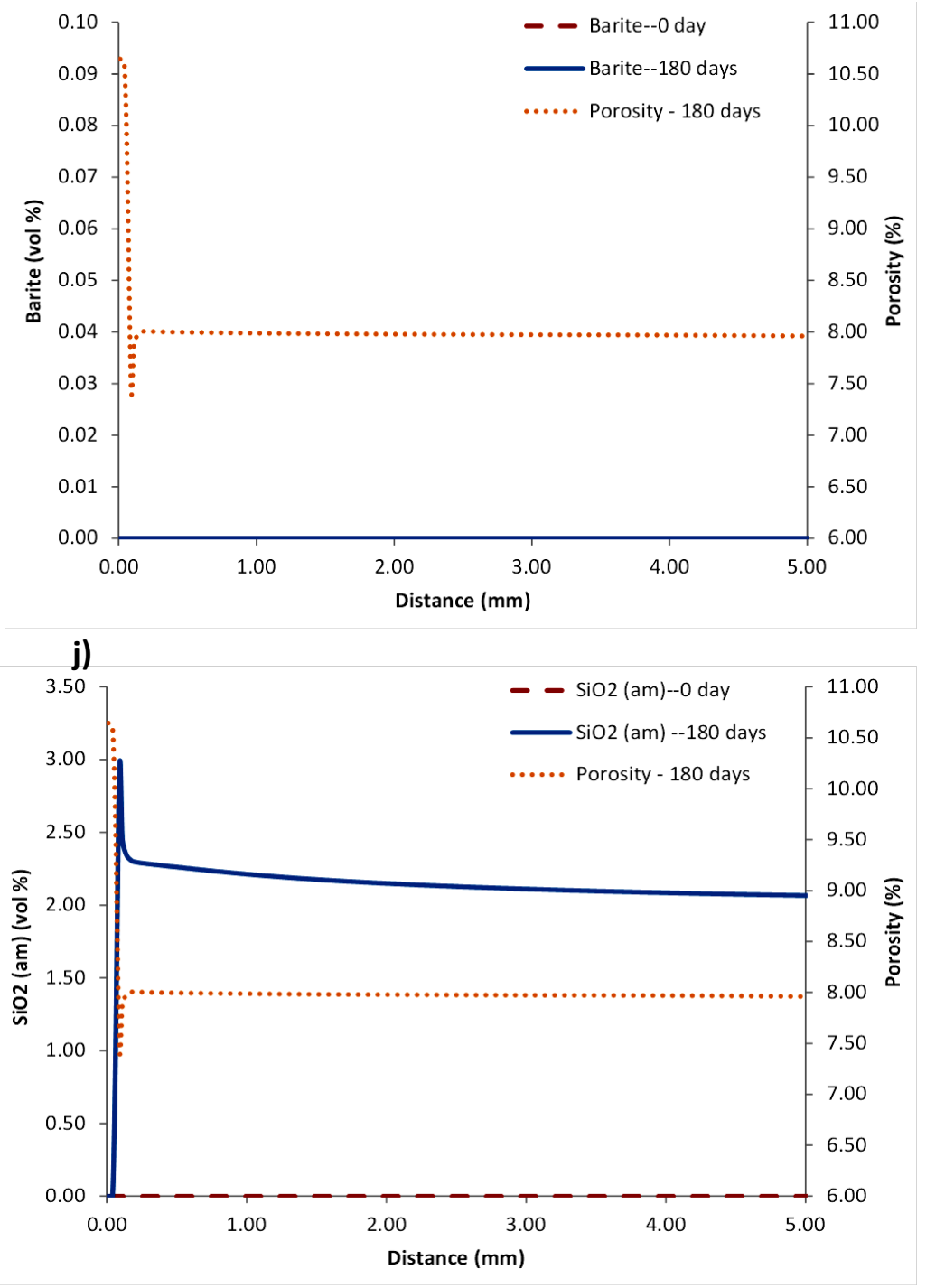
Figure 2: a) Porosity change as a function of distance away from the sandstone surface; b) $\mathrm{pH}$ change as a function of distance away from the sandstone surface; c) total feldspar vol\% change as a function of distance away from the sandstone surface; d) quartz vol\% change as a function of distance away from the sandstone surface; e) annite vol\% change as a function of distance away from the sandstone surface; $\mathrm{f}$ ) muscovite vol\% change as a function of distance away from the sandstone surface; $\mathrm{g}$ ) siderite vol\% change as a function of distance away from the sandstone surface; $h$ ) barite vol\% change as a function of distance away from the sandstone surface; i) kaolinite vol\% change as a function of distance away from the sandstone surface; j) $\mathrm{SiO}_{2}(\mathrm{am}$ ) vol\% change as a function of distance away from the sandstone surface; k) Schematic showing the locations of the high-porosity zone and the low-porosity zone. 
a)
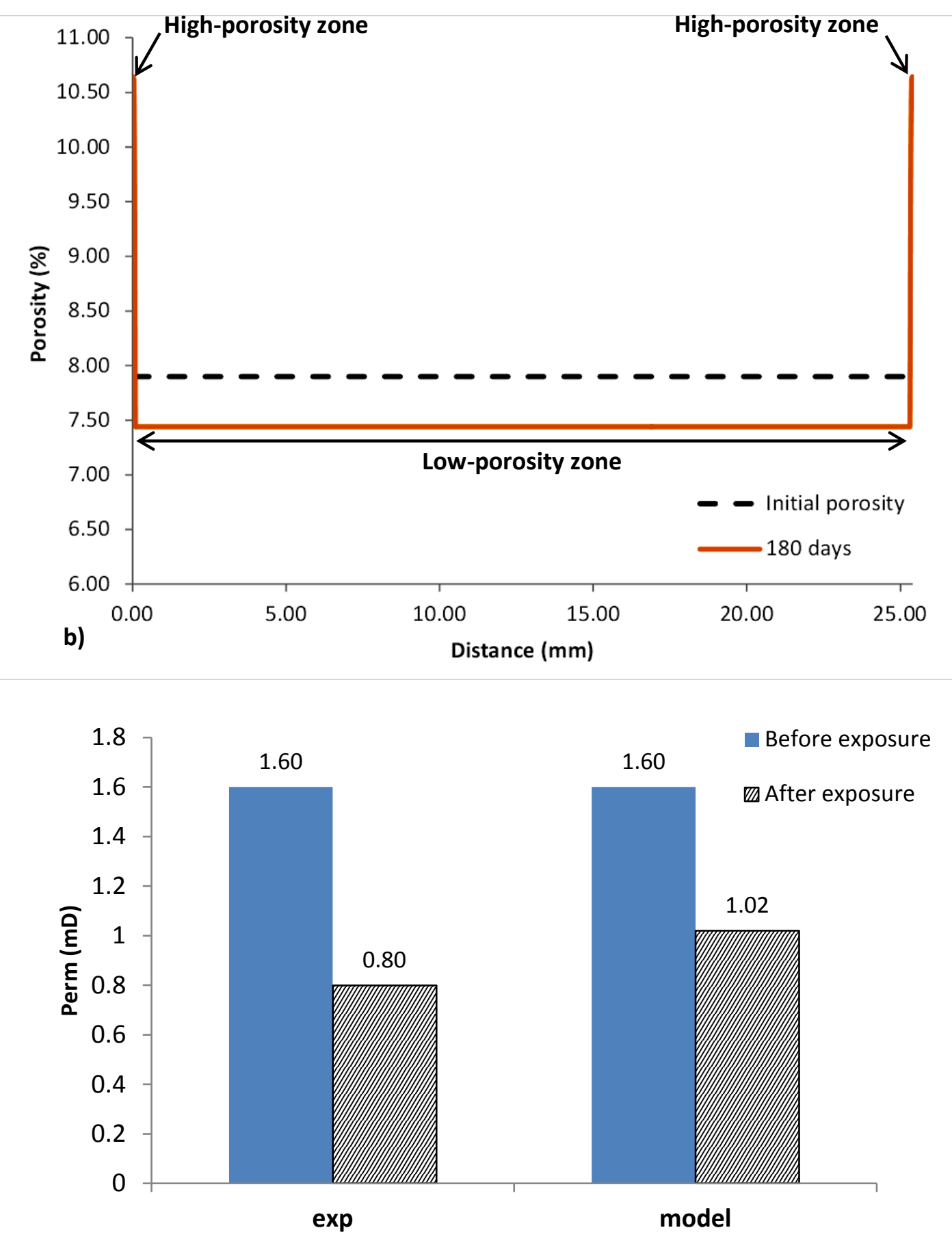

Figure 3: a) Porosity distribution of the lowest-porosity location in Figure S-2 after 180 days of exposure. b) Permeability results of the sandstone sample exposed to $\mathrm{CO}_{2}$-saturated brine for 180 days. 
a)

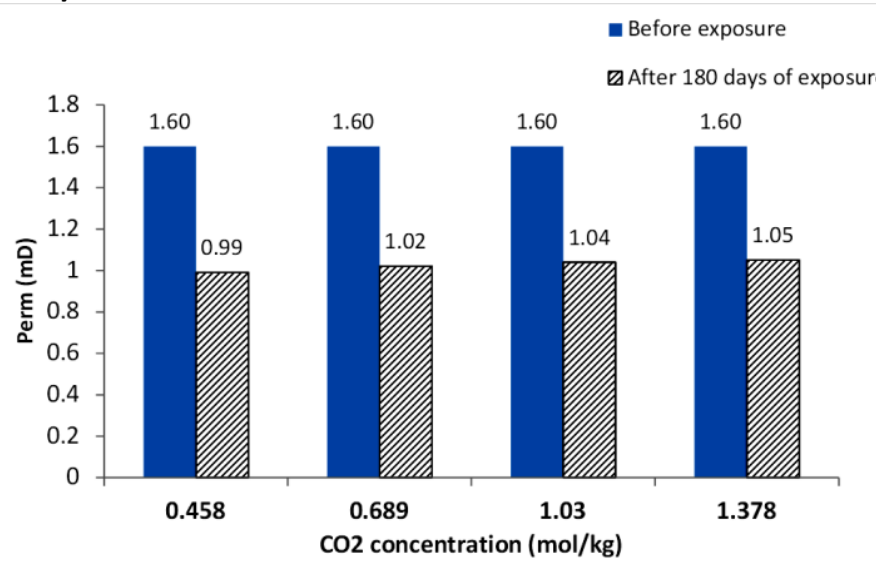

c)

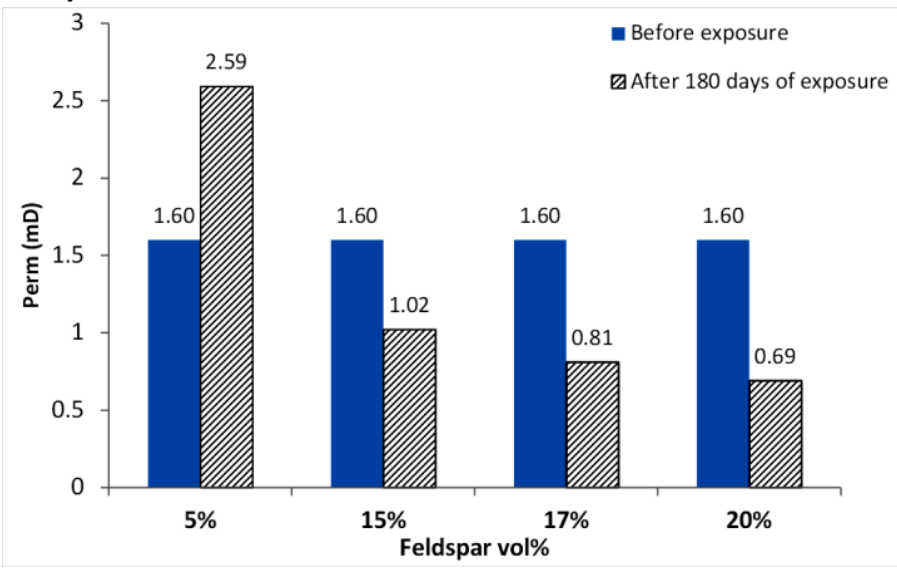

e)

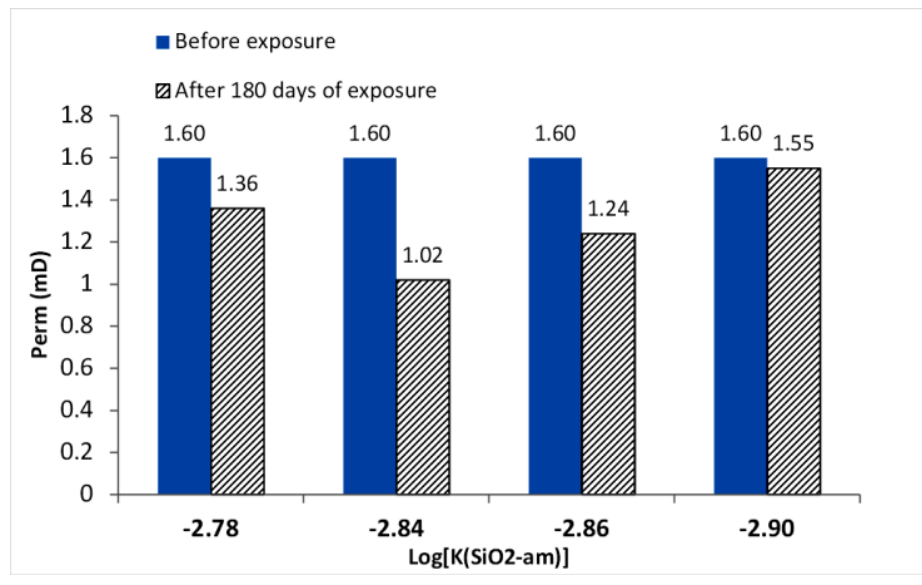

b)

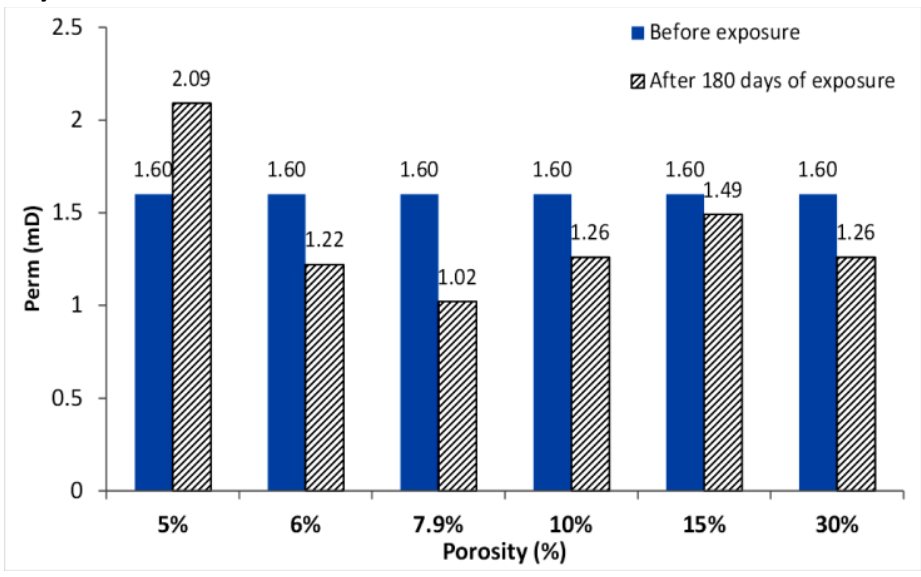

d)

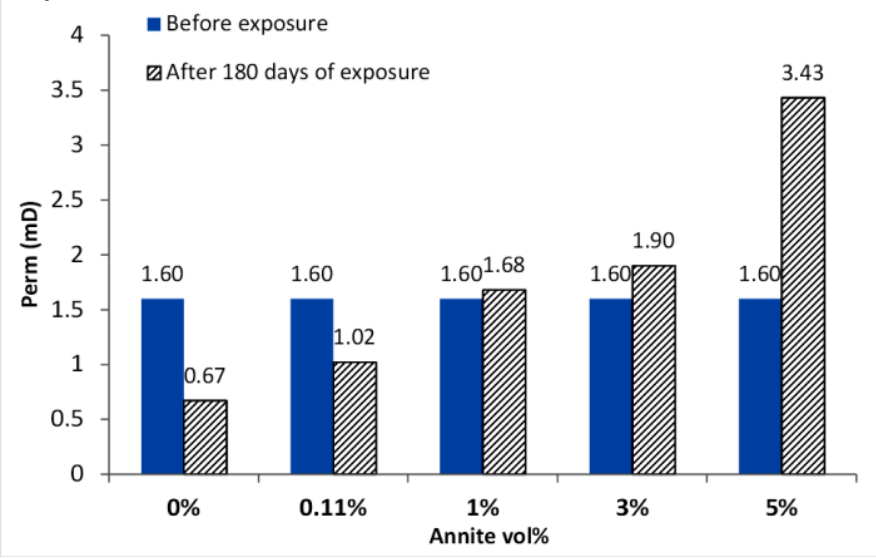

f)

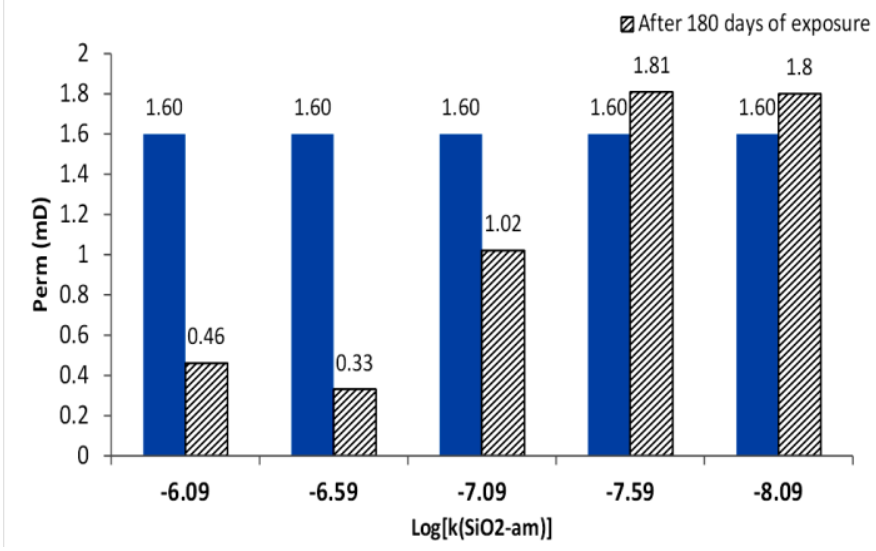




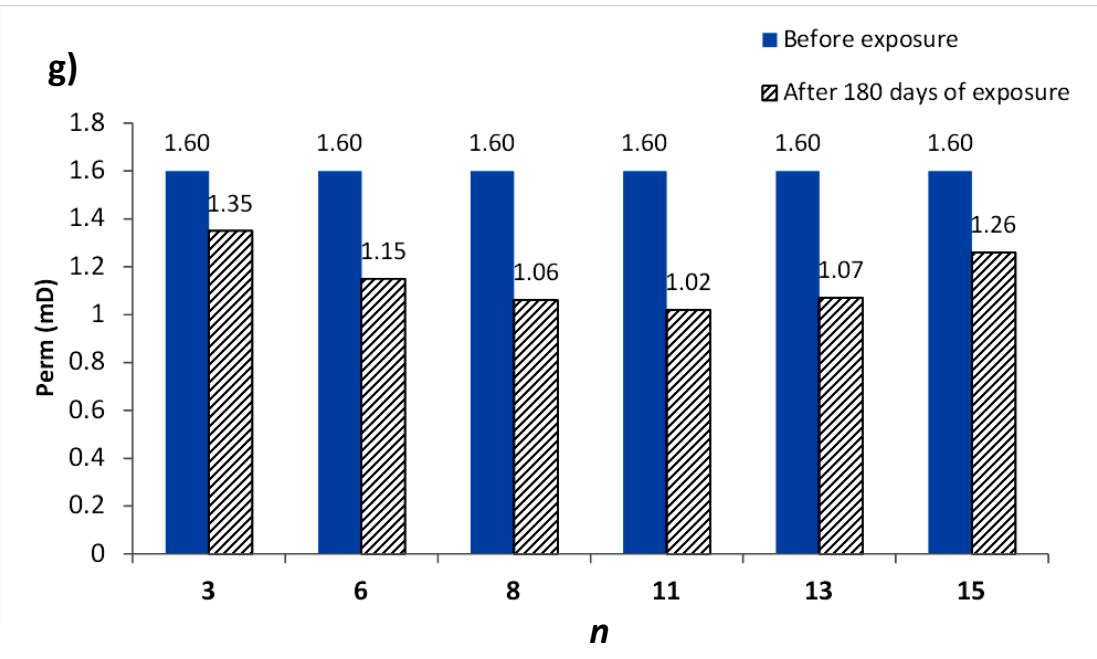

Figure 4: Sensitivity analysis results. a) Effect of aqueous $\mathrm{CO}_{2}$ concentration $(\mathrm{mol} / \mathrm{kg})$ on permeability; b) effect of initial porosity change on permeability; c) effect of feldspar content change on permeability; d) effect of annite content change on permeability; e) effect of $\mathrm{SiO}_{2}$ (am) equilibrium constant change on permeability; f) effect of $\mathrm{SiO}_{2}(\mathrm{am})$ rate constant change on permeability; g) effect of exponent $(n)$ change on permeability. 
a)

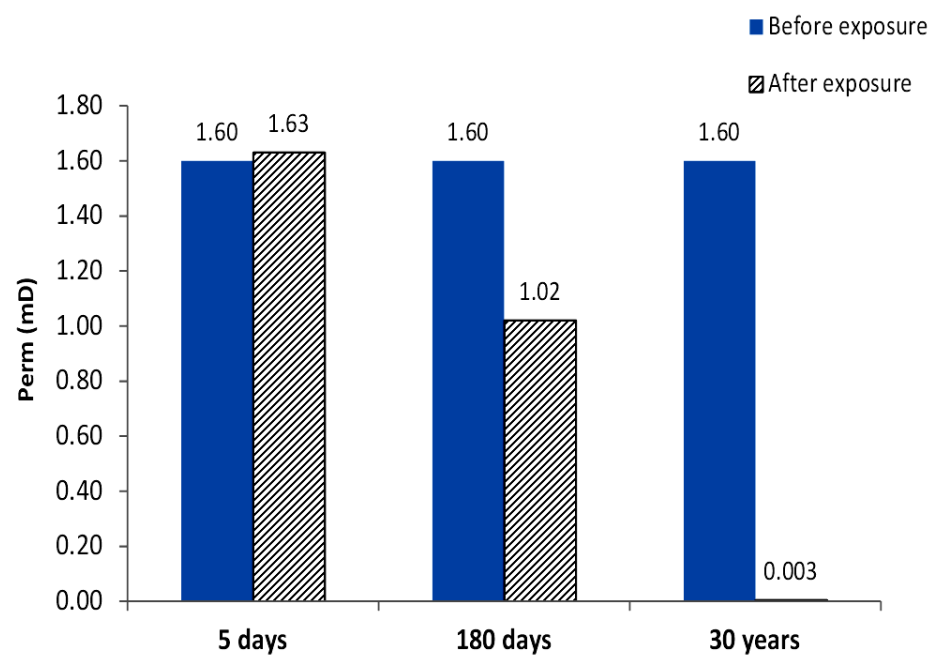

b)

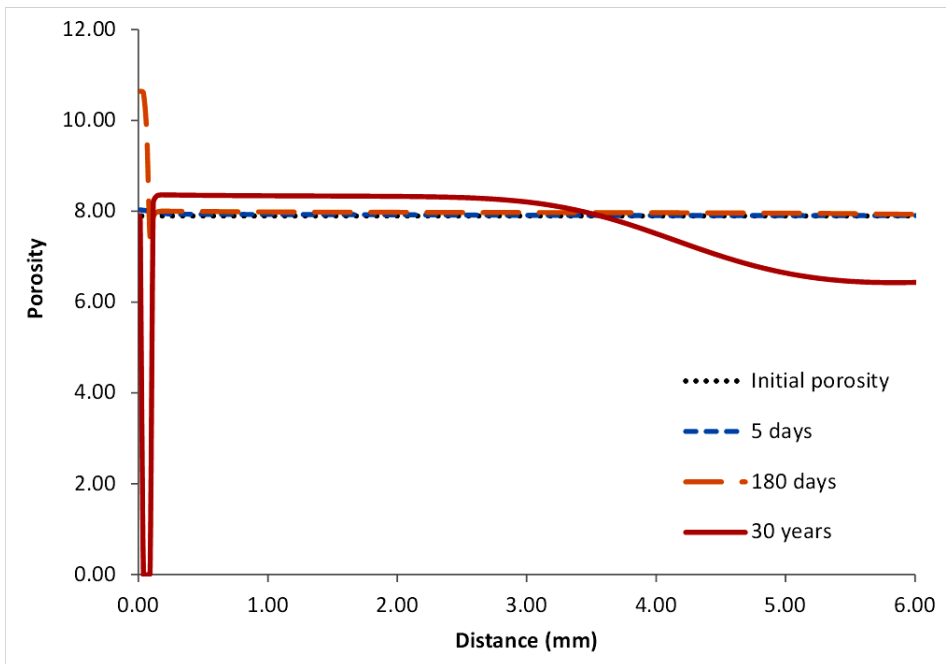

Figure 5: a) Model-predicted permeability change of the sandstone sample exposed to $\mathrm{CO}_{2}$ saturated brine for 5 days, 180 days and 30 years; b) Model-predicted porosity change of the sandstone sample exposed to $\mathrm{CO}_{2}$-saturated brine for 5 days, 180 days and 30 years. 
Table 1: Brine composition reported by Soong et al. (2014) and brine composition used in the model, which takes account of mineral super-saturation at elevated temperature and injection of $\mathrm{CO}_{2}$.

\begin{tabular}{|c|c|}
\hline $\begin{array}{c}\text { Brine composition in Soong et } \\
\text { al. }(2014 \text { ) } \\
\text { (measured at } 25^{\circ} \mathrm{C} \text {; before } \\
\text { injection of } \mathrm{CO}_{2} \text { ) } \\
\text { Unit: } \mathrm{mol} / \mathrm{kg}\end{array}$ & $\begin{array}{l}\text { Brine composition used in } \\
\text { the model } \\
\text { (calculated at } 85^{\circ} \mathrm{C} \text {; after } \\
\text { injection of } \mathrm{CO}_{2} \text { ) } \\
\text { Unit: } \mathrm{mol} / \mathrm{kg}\end{array}$ \\
\hline $\mathrm{pH}=5.40$ & $\mathrm{pH}=4.13$ \\
\hline$\left[\mathrm{H}^{+}\right]=3.59 \mathrm{E}-6$ & {$\left[\mathrm{H}^{+}\right]=7.41 \mathrm{E}-5$} \\
\hline$\left[\mathrm{Ca}^{2+}\right]=0.47$ & {$\left[\mathrm{Ca}^{2+}\right]=0.47$} \\
\hline$\left[\mathrm{Na}^{+}\right]=1.81$ & {$\left[\mathrm{Na}^{+}\right]=1.80$} \\
\hline$\left[\mathrm{Mg}^{2+}\right]=0.099$ & {$\left[\mathrm{Mg}^{2+}\right]=0.099$} \\
\hline$\left[\mathrm{K}^{+}\right]=0.036$ & {$\left[\mathrm{~K}^{+}\right]=0.036$} \\
\hline$\left[\mathrm{Ba}^{2+}\right]=5.71 \mathrm{E}-5$ & {$\left[\mathrm{Ba}^{2+}\right]=9.64 \mathrm{E}-7$} \\
\hline$\left[\mathrm{SO}_{4}{ }^{2-}\right]=4.84 \mathrm{E}-3$ & {$\left[\mathrm{SO}_{4}{ }^{2-}\right]=4.78 \mathrm{E}-3$} \\
\hline$\left[\mathrm{H}_{4} \mathrm{SiO}_{4}\right]=1.61 \mathrm{E}-5$ & {$\left[\mathrm{H}_{4} \mathrm{SiO}_{4}\right]=6.24 \mathrm{E}-6$} \\
\hline$\left[\mathrm{Cl}^{-}\right]=2.97$ & {$\left[\mathrm{Cl}^{-}\right]=2.97$} \\
\hline$\left[\mathrm{Al}^{3+}\right]=1.00 \mathrm{E}-5$ & {$\left[\mathrm{Al}^{3+}\right]=1.15 \mathrm{E}-7$} \\
\hline$\left[\mathrm{Fe}^{2+}\right]=1.42 \mathrm{E}-3$ & {$\left[\mathrm{Fe}^{2+}\right]=1.42 \mathrm{E}-3$} \\
\hline$\left[\mathrm{CO}_{2}\right]_{\mathrm{tot}}=\mathrm{N} / \mathrm{A}$ & {$\left[\mathrm{CO}_{2}\right]_{\text {tot }}=0.689$} \\
\hline
\end{tabular}

Note: All values reported in Table 1 are in the unit of mol/ $\mathrm{kg}$. A brine density of $1.11 \times 10^{3}$ $\mathrm{kg} / \mathrm{m}^{3}$ was used to convert $\mathrm{mg} / \mathrm{L}$ values in Soong et al. (2014) into mol $/ \mathrm{kg}$. The brine density was calculated based on a brine density calculator (Computer Support Group, Inc., 2014). 
Table 2: Mineral composition of unreacted Mount Simon sandstone and minerals produced as a result of the interaction between sandstone and $\mathrm{CO}_{2}$-saturated brine. The composition of unreacted Mount Simon sandstone is assigned based on information in Carroll et al. (2012) and Soong et al. (2014).

\begin{tabular}{|c|c|c|c|}
\hline Mineral name & $\begin{array}{c}\text { Volume percentage } \\
(\% \text {, before reaction } \\
\text { with brine and } \\
\left.\mathrm{CO}_{2}\right)\end{array}$ & $\begin{array}{c}\text { Specific } \\
\text { surface area } \\
\left(\mathbf{m}^{2} / \mathbf{g}\right)\end{array}$ & $\begin{array}{c}\text { Molar } \\
\text { volume } \\
\left(\mathrm{cm}^{3} / \mathrm{mol}\right)\end{array}$ \\
\hline \multicolumn{4}{|c|}{ Mineral composition of unreacted Mount Simon sandstone } \\
\hline $\begin{array}{l}\text { Na-rich feldspar } \\
\quad\left(\mathrm{NaAlSi}_{3} \mathrm{O}_{8}\right)\end{array}$ & 12.9 & $0.39^{\mathrm{a}}$ & $100.4^{b}$ \\
\hline $\begin{array}{l}\text { Ca-rich feldspar } \\
\left(\mathrm{CaAl}_{2} \mathrm{Si}_{2} \mathrm{O}_{8}\right)\end{array}$ & $0.26^{\mathrm{c}}$ & $0.39^{\mathrm{a}}$ & $100.4^{b}$ \\
\hline $\begin{array}{c}\text { Ba-rich feldspar } \\
\left(\mathrm{BaAl}_{2} \mathrm{Si}_{2} \mathrm{O}_{8}\right)\end{array}$ & $3.97 \times 10^{-3 c}$ & $0.39^{\mathrm{a}}$ & $100.4^{b}$ \\
\hline Microcline $\left(\mathrm{KAlSi}_{3} \mathrm{O}_{8}\right)$ & 1.83 & $0.39^{\mathrm{a}}$ & $100.4^{\mathrm{b}}$ \\
\hline Quartz $\left(\mathrm{SiO}_{2}\right)$ & 77.0 & $0.10^{\mathrm{d}}$ & $22.7^{\mathrm{d}}$ \\
\hline Annite $\left(\mathrm{KFe}_{3} \mathrm{AlSi}_{3} \mathrm{O}_{10}(\mathrm{OH})_{2}\right)$ & 0.11 & $7.43^{\mathrm{e}}$ & $154.3^{\mathrm{f}}$ \\
\hline Porosity & 7.9 & -- & -- \\
\hline \multicolumn{4}{|c|}{ Minerals produced as a result of sandstone-brine interaction } \\
\hline $\mathrm{SiO}_{2}(\mathrm{am})$ & 0 & $1.62^{\mathrm{e}}$ & $22.7^{d}$ \\
\hline Kaolinite $\left(\mathrm{Al}_{2} \mathrm{Si}_{2} \mathrm{O}_{5}(\mathrm{OH})_{4}\right)$ & 0 & $15.0^{\mathrm{h}}$ & $99.3^{\mathrm{f}}$ \\
\hline $\begin{array}{c}\text { Muscovite/Illite } \\
\left(K_{0.85} A_{2.85} S_{3.15} O_{10}(O H)_{2}\right)\end{array}$ & 0 & $3.40^{\mathrm{g}}$ & $144.5^{\mathrm{d}}$ \\
\hline Calcite $\left(\mathrm{CaCO}_{3}\right)$ & 0 & $1.00^{\mathrm{d}}$ & $36.9^{f}$ \\
\hline Gypsum $\left(\mathrm{CaSO}_{4} \cdot 2 \mathrm{H}_{2} \mathrm{O}\right)$ & 0 & $7.50^{1}$ & $74.7^{\mathrm{f}}$ \\
\hline Barite $\left(\mathrm{BaSO}_{4}\right)$ & 0 & $1.85^{\mathrm{j}}$ & $52.1^{\mathrm{f}}$ \\
\hline Siderite $\left(\mathrm{FeCO}_{3}\right)$ & 0 & $9.8 \times 10^{-4 \mathrm{k}}$ & $29.4^{\mathrm{f}}$ \\
\hline Dolomite $\left(\mathrm{CaMg}\left(\mathrm{CO}_{3}\right)_{2}\right)$ & 0 & $0.10^{1}$ & $64.3^{f}$ \\
\hline
\end{tabular}

Note:

a: The specific surface area of feldspar is the average of specific surface areas of 9 feldspar powder samples from Casey et al., (1991).

b: Molar volume assumed to be that of albite (Brgm, 2011).

c: Determined from elemental analysis data of the sandstone sample (Soong et al., 2014).

d: Information is from Marty et al. (2009). 
e: Information is from Carroll et al. (2012).

f: Information is from Brgm (2011).

g: Information is from Caseri et al. (1992).

h: The specific surface area of kaolinite is between 10 and $20 \mathrm{~m}^{2} / \mathrm{g}$ (Yong et al., 1992). In this study, a value of $15 \mathrm{~m}^{2} / \mathrm{g}$ is used.

i: Information is from Yu and Brouwers (2011).

$\mathrm{j}$ : Information is from Shen et al. (2009).

k: Information is from Xu et al. (2005).

1: Information is from Wilson et al. (2001). 
Table 3: Summary of important model parameters (equilibrium constants and rate coefficients). $\prod_{i=1}^{\mathrm{N}} \mathrm{a}_{\mathrm{i}}^{\mathrm{p}_{\mathrm{i}}}$ describes the effects of various ions in solution on the dissolution/precipitation rate.

\begin{tabular}{|c|c|c|c|}
\hline Reaction & 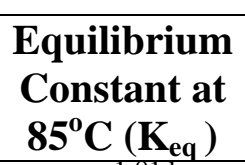 & $\begin{array}{l}\text { Rate Coefficient at } \\
85^{\circ} \mathrm{C}, \boldsymbol{k},\left(\mathrm{mol} /\left(\mathrm{m}^{2} \mathrm{~s}\right)^{\mathrm{a}}\right.\end{array}$ & Value of $\prod_{i=1}^{N} a_{i}^{p_{i}}$ \\
\hline $\begin{array}{c}\text { quartz dissolution/precipitation }\left(85^{\circ} \mathrm{C}\right) \\
\qquad \mathrm{SiO}_{2}+2 \mathrm{H}_{2} \mathrm{O} \leftrightarrow \mathrm{H}_{4} \mathrm{SiO}_{4}(\mathrm{aq})\end{array}$ & $10^{-1.81 \mathrm{~b}}$ & $10^{-11.38}$ & 1.0 \\
\hline $\begin{array}{c}\mathrm{SiO}_{2}(\mathrm{am}) \text { dissolution/precipitation }\left(85^{\circ} \mathrm{C}\right) \\
\mathrm{SiO}_{2}(\mathrm{am})+2 \mathrm{H}_{2} \mathrm{O} \leftrightarrow \mathrm{H}_{4} \mathrm{SiO}_{4}(\mathrm{aq})\end{array}$ & $10^{-2.84 c}$ & $10^{-7.09}$ & 1.0 \\
\hline $\begin{array}{l}\text { Na-rich feldspar dissolution/precipitation }\left(85^{\circ} \mathrm{C}\right) \\
\mathrm{NaAlSi}_{3} \mathrm{O}_{8}+4 \mathrm{H}^{+}+4 \mathrm{H}_{2} \mathrm{O} \\
\leftrightarrow \mathrm{Na}^{+}+\mathrm{Al}^{3+}+3 \mathrm{H}_{4} \mathrm{SiO}_{4}(\mathrm{aq})\end{array}$ & $10^{-0.64 b}$ & $\begin{array}{c}\text { For } \mathrm{pH} \text {-independent } \\
\text { dissolution/ } \\
\text { precipitation, } \\
\mathrm{k}_{1}=10^{-11.29} \text {; } \\
\text { For } \mathrm{pH} \text {-dependent } \\
\text { dissolution, } \\
\mathrm{k}_{2}=10^{-8.54}\end{array}$ & $\begin{array}{c}\text { For } \mathrm{pH} \text {-independent } \\
\text { dissolution/ } \\
\text { precipitation, } \\
\prod_{\mathrm{i}=1}^{\mathrm{N}} \mathrm{a}_{\mathrm{i}}=1.0 ; \\
\text { For } \mathrm{pH} \text {-dependent } \\
\text { dissolution, } \\
\prod_{\mathrm{i}=1}^{\mathrm{N}} \mathrm{a}_{\mathrm{i}}^{\mathrm{p}_{\mathrm{i}}}=\left[H^{+}\right]^{0.5}\end{array}$ \\
\hline $\begin{array}{l}\text { Ca-rich feldspar dissolution/precipitation }\left(85^{\circ} \mathrm{C}\right) \\
\mathrm{CaAl}_{2} \mathrm{Si}_{2} \mathrm{O}_{8}+8 \mathrm{H}^{+} \\
\leftrightarrow \mathrm{Ca}^{2+}+2 \mathrm{Al}^{3+}+2 \mathrm{H}_{4} \mathrm{SiO}_{4}(\mathrm{aq})\end{array}$ & $10^{16.53 b}$ & $\begin{array}{c}\text { For } \mathrm{pH} \text {-independent } \\
\text { dissolution/ } \\
\text { precipitation, } \\
\mathrm{k}_{1}=10^{-11.29} ; \\
\text { For } \mathrm{pH} \text {-dependent } \\
\text { dissolution, } \\
\mathrm{k}_{2}=10^{-8.54}\end{array}$ & $\begin{array}{c}\text { For } \mathrm{pH} \text {-independent } \\
\text { dissolution/ } \\
\text { precipitation, } \\
\prod_{\mathrm{i}=1}^{\mathrm{N}} \mathrm{a}_{\mathrm{i}}=1.0 ; \\
\text { For } \mathrm{pH} \text {-dependent } \\
\text { dissolution, } \\
\prod_{\mathrm{i}=1}^{\mathrm{N}} \mathrm{a}_{\mathrm{i}}^{\mathrm{p}_{\mathrm{i}}}=\left[H^{+}\right]^{0.5}\end{array}$ \\
\hline $\begin{array}{l}\text { Ba-bearing feldspar dissolution/precipitation }\left(85^{\circ} \mathrm{C}\right) \\
\mathrm{BaAl}_{2} \mathrm{Si}_{2} \mathrm{O}_{8}+8 \mathrm{H}^{+} \\
\leftrightarrow \mathrm{Ba}^{2+}+2 \mathrm{Al}^{3+}+2 \mathrm{H}_{4} \mathrm{SiO}_{4}(\mathrm{aq})\end{array}$ & $10^{16.53 d}$ & $\begin{array}{c}\text { For } \mathrm{pH} \text {-independent } \\
\text { dissolution/ } \\
\text { precipitation, } \\
\mathrm{k}_{1}=10^{-11.29} ; \\
\text { For } \mathrm{pH} \text {-dependent } \\
\text { dissolution, } \\
\mathrm{k}_{2}=10^{-8.54}\end{array}$ & $\begin{array}{c}\text { For } \mathrm{pH} \text {-independent } \\
\text { dissolution/ } \\
\text { precipitation, } \\
\prod_{\mathrm{i}=1}^{\mathrm{N}} \mathrm{a}_{\mathrm{i}}=1.0 ; \\
\text { For } \mathrm{pH} \text {-dependent } \\
\text { dissolution, } \\
\prod_{\mathrm{i}=1}^{\mathrm{N}} \mathrm{a}_{\mathrm{i}}^{\mathrm{p}_{\mathrm{i}}}=\left[H^{+}\right]^{0.5}\end{array}$ \\
\hline $\begin{array}{l}\text { microcline dissolution/precipitation }\left(85^{\circ} \mathrm{C}\right) \\
\qquad \begin{array}{l}\mathrm{KAlSi}_{3} \mathrm{O}_{8}+4 \mathrm{H}^{+}+4 \mathrm{H}_{2} \mathrm{O} \\
\leftrightarrow \mathrm{K}^{+}+\mathrm{Al}^{3+}+3 \mathrm{H}_{4} \mathrm{SiO}_{4}(\mathrm{aq})\end{array}\end{array}$ & $10^{-1.58 b}$ & $\begin{array}{c}\text { For } \mathrm{pH} \text {-independent } \\
\text { dissolution/ } \\
\text { precipitation, } \\
\mathrm{k}_{1}=10^{-11.29} \text {; } \\
\text { For } \mathrm{pH} \text {-dependent } \\
\text { dissolution, } \\
\mathrm{k}_{2}=10^{-8.54} \text {. }\end{array}$ & $\begin{array}{c}\text { For } \mathrm{pH} \text {-independent } \\
\text { dissolution/ } \\
\text { precipitation, } \\
\prod_{\mathrm{i}=1}^{\mathrm{N}} \mathrm{a}_{\mathrm{i}}=1.0 ; \\
\text { For } \mathrm{pH} \text {-dependent } \\
\text { dissolution, } \\
\prod_{\mathrm{i}=1}^{\mathrm{N}} \mathrm{a}_{\mathrm{i}}^{\mathrm{p}_{\mathrm{i}}}=\left[H^{+}\right]^{0.5}\end{array}$ \\
\hline
\end{tabular}




\begin{tabular}{|c|c|c|c|}
\hline $\begin{array}{c}\text { annite dissolution/precipitation }\left(85^{\circ} \mathrm{C}\right) \\
\mathrm{KFe}_{3} \mathrm{AlSi}_{3} \mathrm{O}_{10}(\mathrm{OH})_{2}+10 \mathrm{H}^{+} \leftrightarrow \mathrm{Al}^{3+}+3 \mathrm{Fe}^{2+}+ \\
\mathrm{K}^{+}+3 \mathrm{H}_{4} \mathrm{SiO}_{4}(\mathrm{aq})\end{array}$ & $10^{20.83 e}$ & $\begin{array}{c}\text { For } \mathrm{pH} \text {-independent } \\
\text { dissolution/ } \\
\text { precipitation, } \mathrm{k}_{1}= \\
10^{-11.49} ; \\
\text { For } \mathrm{pH} \text {-dependent } \\
\text { dissolution, } \\
\mathrm{k}_{2}=10^{-8.49}\end{array}$ & $\begin{array}{c}\text { For reaction }(1), \\
\prod_{i=1}^{N} a_{i}^{p_{i}}=1.0 ; \\
\text { For reaction }(2), \\
\prod_{i=1}^{N} a_{i}^{p_{i}}=\left[H^{+}\right]^{0.53}\end{array}$ \\
\hline $\begin{array}{l}\text { kaolinite dissolution/precipitation }\left(85^{\circ} \mathrm{C}\right) \\
\qquad \mathrm{Al}_{2} \mathrm{Si}_{2} \mathrm{O}_{5}(\mathrm{OH})_{4}+6 \mathrm{H}^{+} \\
\leftrightarrow 2 \mathrm{Al}^{3+}+\mathrm{H}_{2} \mathrm{O}+2 \mathrm{H}_{4} \mathrm{SiO}_{4}(\mathrm{aq})\end{array}$ & $10^{1.56 b}$ & $\begin{array}{l}\text { For dissolution, } \mathrm{k} \\
=10^{-10.10} \text {; for } \\
\text { precipitation, } \\
\mathrm{k}=10^{-12.15}\end{array}$ & $\begin{array}{c}\text { For dissolution, } \\
\prod_{i=1}^{N} a_{i}^{p_{i}}=\left[\mathrm{H}^{+}\right]^{0.4} ; \text { for } \\
\text { precipitation, } \\
\prod_{i=1}^{N} a_{i}^{p_{i}}=\left[\mathrm{Al}^{3+}\right]\end{array}$ \\
\hline $\begin{array}{l}\text { barite dissolution/precipitation }\left(85^{\circ} \mathrm{C}\right) \\
\qquad \mathrm{BaSO}_{4} \leftrightarrow \mathrm{Ba}^{2+}+\mathrm{SO}_{4}^{2-}\end{array}$ & $10^{-9.61 b}$ & $10^{2.97}$ & {$\left[\mathrm{Ba}^{2+}\right]\left[\mathrm{SO}_{4}^{2-}\right]$} \\
\hline $\begin{array}{l}\text { gypsum dissolution/precipitation }\left(85^{\circ} \mathrm{C}\right) \\
\mathrm{CaSO}_{4} \cdot 2 \mathrm{H}_{2} \mathrm{O} \leftrightarrow \mathrm{Ca}^{2+}+\mathrm{SO}_{4}^{2-}+2 \mathrm{H}_{2} \mathrm{O}\end{array}$ & $10^{-4.885 b}$ & $10^{-4.16}$ & 1.0 \\
\hline $\begin{array}{c}\text { siderite dissolution/precipitation }\left(85^{\circ} \mathrm{C}\right) \\
\mathrm{FeCO} \mathrm{O}_{3}+\mathrm{H}^{+} \leftrightarrow \mathrm{Fe}^{2+}+\mathrm{HCO}_{3}^{-}\end{array}$ & $10^{-1.20 b}$ & $10^{-7.7}$ & {$\left[\mathrm{HCO}_{3}{ }^{-}\right]$} \\
\hline $\begin{array}{c}\text { muscovite/illite dissolution/precipitation }\left(85^{\circ} \mathrm{C}\right) \\
\mathrm{KAl}_{3} \mathrm{Si}_{3} \mathrm{O}_{10}(\mathrm{OH})_{2}+10 \mathrm{H}^{+} \leftrightarrow 3 \mathrm{Al}^{3+}+\mathrm{K}^{+}+ \\
3 \mathrm{H}_{4} \mathrm{SiO}_{4}(\mathrm{aq})\end{array}$ & $10^{5.96 b}$ & $10^{-10.33}$ & 1.0 \\
\hline $\begin{array}{l}\text { dolomite dissolution/precipitation }\left(85^{\circ} \mathrm{C}\right) \\
\mathrm{CaMg}\left(\mathrm{CO}_{3}\right)_{2}+2 \mathrm{H}^{+} \leftrightarrow \mathrm{Ca}^{2+}+\mathrm{Mg}^{2+}+2 \mathrm{HCO}_{3}^{-}\end{array}$ & $10^{1.425 b}$ & $10^{-14.43}$ & 1.0 \\
\hline $\begin{array}{l}\text { calcite dissolution/precipitation }\left(85^{\circ} \mathrm{C}\right) \\
\qquad \mathrm{CaCO}_{3}+\mathrm{H}^{+} \leftrightarrow \mathrm{Ca}^{2+}+\mathrm{HCO}_{3}^{-}\end{array}$ & $10^{0.68 b}$ & $\begin{array}{l}\text { For dissolution, } \\
\mathrm{k}=10^{-2.01} \text {; for } \\
\text { precipitation, } \\
\mathrm{k}=10^{-7.31}\end{array}$ & $\begin{array}{c}\text { For dissolution, } \\
\prod_{\mathrm{i}=1}^{\mathrm{N}} \mathrm{a}_{\mathrm{i}}^{\mathrm{p}_{\mathrm{i}}}=\left[\mathrm{H}^{+}\right] \text {; for } \\
\text { precipitation, } \\
\prod_{\mathrm{i}=1}^{\mathrm{N}} \mathrm{a}_{\mathrm{i}} \mathrm{p}_{\mathrm{i}} \\
{\left[\mathrm{Ca}^{2+}\right]\left[\mathrm{HCO}_{3}^{-}\right]}\end{array}$ \\
\hline
\end{tabular}

Notes:

a: Details about the calculation of reaction rate constants can be found in Supporting Information.

b: Information is from Brgm (2011).

c: Reduced from the value of $10^{-1.56}$ in Carroll et al. (2012) to fit solution chemistry data.

$\mathrm{d}$ : $\mathrm{K}_{\mathrm{eq}}$ for Ba-bearing feldspar dissolution reaction is assumed to be the same as that for Ca-rich feldspar dissolution reaction.

e: Here annite is used as a proxy of Fe-rich clay in the sandstone. The $\mathrm{K}_{\mathrm{eq}}$ value is derived from Carroll et al. (2012). 
Table 4: Justification to choose each parameter for sensitivity analysis and the values tested for each parameter

\begin{tabular}{|c|c|c|}
\hline Parameter & Reason to test this parameter & Values tested \\
\hline $\begin{array}{l}\text { Initial concentration of } \\
\text { dissolved } \mathrm{CO}_{2}\end{array}$ & $\begin{array}{l}\text { Aqueous } \mathrm{CO}_{2} \text { concentration determines } \mathrm{pH} \text {, } \\
\text { which determines how fast the feldspar can } \\
\text { dissolve to provide } \mathrm{H}_{4} \mathrm{SiO}_{4}(\mathrm{aq})\end{array}$ & $\begin{array}{l}0.458,0.689,1.03 \\
1.378 \mathrm{~mol} / \mathrm{kg}\end{array}$ \\
\hline Initial porosity & $\begin{array}{l}\text { Important parameter in eqn. } 4, \text { which } \\
\text { calculates permeability change }\end{array}$ & $5,6,7.9,10,15,30 \%$ \\
\hline Initial feldspar content & $\begin{array}{l}\text { Important parameter to determine how } \\
\text { much feldspar can dissolve to provide } \\
\qquad \mathrm{H}_{4} \mathrm{SiO}_{4}(\mathrm{aq})\end{array}$ & $5,15,17,20 \%$ \\
\hline Initial annite content & $\begin{array}{c}\text { The annite content determines how much } \\
\text { aqueous iron can be provided to form } \\
\text { siderite }\end{array}$ & $0,0.11,1,3,5 \%$ \\
\hline $\mathrm{K}_{\mathrm{eq}}\left(\mathrm{SiO}_{2}(\mathrm{am})\right)$ & $\begin{array}{c}\mathrm{K}_{\mathrm{eq}}\left(\mathrm{SiO}_{2}(\mathrm{am})\right) \text { determines how fast } \mathrm{SiO}_{2} \\
\text { (am) can precipitate }\end{array}$ & 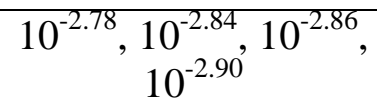 \\
\hline $\mathrm{k}\left(\mathrm{SiO}_{2}(\mathrm{am})\right)$ & $\begin{array}{c}\mathrm{k}\left(\mathrm{SiO}_{2}(\mathrm{am})\right) \text { determines how fast } \mathrm{SiO}_{2}(\mathrm{am}) \\
\text { can precipitate }\end{array}$ & $\begin{array}{c}10^{-6.09}, 10^{-6.59}, 10^{-7.09} \\
10^{-7.59}, 10^{-8.09} \\
\mathrm{~mol} /\left(\mathrm{m}^{2} \mathrm{~s}\right)\end{array}$ \\
\hline Exponent $n$ & $\begin{array}{l}\text { Important parameter in eqn. } 4 \text {, which } \\
\text { calculates permeability change }\end{array}$ & $3,6,8,11,13,15$ \\
\hline
\end{tabular}


Table 5: Comparison between model-predicted major element concentration and laboratorymeasured major element concentration in brine after 180 days of exposure.

\begin{tabular}{|c|c|c|}
\hline Element & $\begin{array}{c}\text { Measured } \\
\text { concentration } \\
\text { (mg/kg water) }\end{array}$ & $\begin{array}{c}\text { Model- } \\
\text { predicted } \\
\text { concentration } \\
\text { (mg/kg water) }\end{array}$ \\
\hline $\mathrm{Ca}$ & 19725 & 18806 \\
\hline $\mathrm{Na}$ & 35612 & 34143 \\
\hline $\mathrm{Mg}$ & 2514 & 2376 \\
\hline $\mathrm{K}$ & 1463 & 1458 \\
\hline $\mathrm{Fe}$ & 92.7 & 128 \\
\hline $\mathrm{Si}$ & 10.45 & 13.59 \\
\hline
\end{tabular}

